Atmos. Chem. Phys., 10, 9415-9429, 2010

www.atmos-chem-phys.net/10/9415/2010/

doi:10.5194/acp-10-9415-2010

(C) Author(s) 2010. CC Attribution 3.0 License.

\title{
HO $_{\mathrm{x}}$ observations over West Africa during AMMA: impact of isoprene and $\mathrm{NO}_{\mathrm{x}}$
}

\author{
D. Stone ${ }^{1,2}$, M. J. Evans ${ }^{1}$, R. Commane ${ }^{2, *}$, T. Ingham ${ }^{2,3}$, C. F. A. Floquet ${ }^{2, * *}$, J. B. McQuaid ${ }^{1}$, D. M. Brookes ${ }^{4}$, \\ P. S. Monks ${ }^{4}$, R. Purvis ${ }^{5,6}$, J. F. Hamilton ${ }^{6}$, J. Hopkins ${ }^{6,7}$, J. Lee ${ }^{6,7}$, A. C. Lewis ${ }^{6,7}$, D. Stewart ${ }^{8}$, J. G. Murphy ${ }^{8, * *}{ }^{*}$, \\ G. Mills ${ }^{8}$, D. Oram ${ }^{8}$, C. E. Reeves ${ }^{8}$, and D. E. Heard ${ }^{2,3}$ \\ ${ }^{1}$ School of Earth and Environment, University of Leeds, Leeds, UK \\ ${ }^{2}$ School of Chemistry, University of Leeds, Leeds, UK \\ ${ }^{3}$ National Centre for Atmospheric Science, University of Leeds, Leeds, UK \\ ${ }^{4}$ Department of Chemistry, University of Leicester, Leicester, UK \\ ${ }^{5}$ Facility for Airborne Atmospheric Measurement, Cranfield University, Cranfield, UK \\ ${ }^{6}$ Department of Chemistry, University of York, York, UK \\ ${ }^{7}$ National Centre for Atmospheric Science, University of York, York, UK \\ ${ }^{8}$ School of Environmental Sciences, University of East Anglia, Norwich, UK \\ * now at: School of Engineering \& Applied Sciences, Harvard University, Cambridge, USA \\ ** now at: National Oceanography Centre, University of Southampton, Southampton, UK \\ ${ }^{* * *}$ now at: Department of Chemistry, University of Toronto, Toronto, Canada
}

Received: 24 June 2010 - Published in Atmos. Chem. Phys. Discuss.: 12 July 2010

Revised: 14 September 2010 - Accepted: 26 September 2010 - Published: 6 October 2010

\begin{abstract}
Aircraft $\mathrm{OH}$ and $\mathrm{HO}_{2}$ measurements made over West Africa during the AMMA field campaign in summer 2006 have been investigated using a box model constrained to observations of long-lived species and physical parameters. "Good" agreement was found for $\mathrm{HO}_{2}$ (modelled to observed gradient of $1.23 \pm 0.11$ ). However, the model significantly overpredicts $\mathrm{OH}$ concentrations. The reasons for this are not clear, but may reflect instrumental instabilities affecting the $\mathrm{OH}$ measurements. Within the model, $\mathrm{HO}_{\mathrm{x}}$ concentrations in West Africa are controlled by relatively simple photochemistry, with production dominated by ozone photolysis and reaction of $\mathrm{O}\left({ }^{1} \mathrm{D}\right)$ with water vapour, and loss processes dominated by $\mathrm{HO}_{2}+\mathrm{HO}_{2}$ and $\mathrm{HO}_{2}+\mathrm{RO}_{2}$. Isoprene chemistry was found to influence forested regions. In contrast to several recent field studies in very low $\mathrm{NO}_{\mathrm{x}}$ and high isoprene environments, we do not observe any dependence of model success for $\mathrm{HO}_{2}$ on isoprene and attribute this to efficient recycling of $\mathrm{HO}_{\mathrm{x}}$ through
\end{abstract}

Correspondence to: M. J. Evans

(m.j.evans@leeds.ac.uk)
$\mathrm{RO}_{2}+\mathrm{NO}$ reactions under the moderate $\mathrm{NO}_{\mathrm{x}}$ concentrations (5-300 ppt NO in the boundary layer, median $76 \mathrm{ppt}$ ) encountered during AMMA. This suggests that some of the problems with understanding the impact of isoprene on atmospheric composition may be limited to the extreme low range of $\mathrm{NO}_{\mathrm{x}}$ concentrations.

\section{Introduction}

Tropospheric oxidation is responsible for the removal of many species from the atmosphere which would otherwise build up to dangerous concentrations. This is predominantly achieved through reaction with the hydroxyl radical $(\mathrm{OH})$. For most of the troposphere, $\mathrm{OH}$ is produced through the short wavelength solar photolysis of $\mathrm{O}_{3}$ in the presence of water vapour:

$\mathrm{O}_{3}+h v(\lambda<340 \mathrm{~nm}) \longrightarrow \mathrm{O}\left({ }^{1} \mathrm{D}\right)+\mathrm{O}_{2}$

$\mathrm{O}\left({ }^{1} \mathrm{D}\right)+\mathrm{H}_{2} \mathrm{O} \longrightarrow 2 \mathrm{OH}$

Published by Copernicus Publications on behalf of the European Geosciences Union. 
$\mathrm{OH}$ radicals have a short lifetime in the atmosphere. They react rapidly with $\mathrm{CO}$ to produce hydroperoxy radicals $\left(\mathrm{HO}_{2}\right)$, which can regenerate $\mathrm{OH}$ by reaction with $\mathrm{O}_{3}$ or NO:

$$
\begin{aligned}
& \mathrm{CO}+\mathrm{OH}(+\mathrm{M}) \longrightarrow \mathrm{HO}_{2}+\mathrm{CO}_{2}(+\mathrm{M}) \\
& \mathrm{HO}_{2}+\mathrm{O}_{3} \longrightarrow \mathrm{OH}+2 \mathrm{O}_{2} \\
& \mathrm{HO}_{2}+\mathrm{NO} \longrightarrow \mathrm{OH}+\mathrm{NO}_{2}
\end{aligned}
$$

This interconversion of $\mathrm{OH}$ and $\mathrm{HO}_{2}$ can also occur through reactions of $\mathrm{OH}$ with VOCs (shown for a general hydrocarbon (RH) in reactions R5-R8) through the production of organic peroxy radicals $\left(\mathrm{RO}_{2}\right)$ and their subsequent reaction with NO:

$$
\begin{aligned}
& \mathrm{OH}+\mathrm{RH} \longrightarrow \mathrm{R}+\mathrm{H}_{2} \mathrm{O} \\
& \mathrm{R}+\mathrm{O}_{2}+\mathrm{M} \longrightarrow \mathrm{RO}_{2}+\mathrm{M} \\
& \mathrm{RO}_{2}+\mathrm{NO} \longrightarrow \mathrm{RO}+\mathrm{NO}_{2} \\
& \mathrm{RO}+\mathrm{O}_{2} \longrightarrow \mathrm{R}^{\prime} \mathrm{CHO}+\mathrm{HO}_{2}
\end{aligned}
$$

Chain termination occurs through peroxy-peroxy reactions, the reaction between $\mathrm{OH}$ and $\mathrm{NO}_{2}$ and heterogenous uptake of $\mathrm{HO}_{2}$ (R10-R13) (Jaegle et al., 2000; Monks, 2004; Olson et al., 2004):

$\mathrm{HO}_{2}+\mathrm{HO}_{2}(+\mathrm{M}) \longrightarrow \mathrm{H}_{2} \mathrm{O}_{2}+\mathrm{O}_{2}(+\mathrm{M})$

$\mathrm{HO}_{2}+\mathrm{RO}_{2} \longrightarrow \mathrm{ROOH}+\mathrm{O}_{2}$

$\mathrm{OH}+\mathrm{NO}_{2} \longrightarrow \mathrm{HNO}_{3}$

$\mathrm{HO}_{2}+$ aerosol $\longrightarrow$ products

As a result of the rapid interconversion between $\mathrm{OH}$ and $\mathrm{HO}_{2}$, the two species are often considered together as $\mathrm{HO}_{\mathrm{x}}$ $\left(\left[\mathrm{HO}_{\mathrm{x}}\right]=[\mathrm{OH}]+\left[\mathrm{HO}_{2}\right]\right)$. Owing to the intense radiation and high humidity which enhances primary production, the tropics are thought to possess the highest concentrations of $\mathrm{OH}$, and are thus of central importance for the removal of many long lived gases such as $\mathrm{CH}_{4}$ (Bloss et al., 2005).

Observations of $\mathrm{HO}_{\mathrm{x}}$ in tropical regions have been made on a number of previous field campaigns. The Pacific Exploratory Mission (PEM) Tropics-B campaign (Tan et al., 2001) made aircraft measurements of $\mathrm{OH}$ and $\mathrm{HO}_{2}$ over the tropical South Pacific Ocean. Using a photochemical box model, Olson et al. (2001) found $\mathrm{OH}$ to be overpredicted at low altitudes and underpredicted at higher altitudes, with a mean modelled to measured ratio of 0.86 . Simulations of $\mathrm{HO}_{2}$ gave a mean modelled to measured ratio of 1.03.

The Intercontinental Chemical Transport Experiment B (INTEX-B) aircraft campaign over the North Pacific and western coast of North America made measurements of $\mathrm{OH}$ and $\mathrm{HO}_{2}$ (Mao et al., 2009; Singh et al., 2009). Model calculations overpredicted the $\mathrm{OH}$ concentrations (Mao et al., 2009), particularly at altitudes less than $2 \mathrm{~km}$, but found the overprediction to correlate with $\mathrm{HCHO}$ concentrations, indicating missing reactive VOCs in the model (Mao et al., 2009). Modelled $\mathrm{HO}_{2}$ concentrations were generally found to agree with observations (Mao et al., 2009).

While $\mathrm{HO}_{\mathrm{x}}$ observations in marine tropical environments have generally been explained by modelling studies, fewer observations have been made in tropical forest regions to validate model predictions. Until recently, $\mathrm{OH}$ concentrations in forested regions have been expected to remain low as a result of high emissions of biogenic compounds such as isoprene $\left(\mathrm{C}_{5} \mathrm{H}_{8}\right)$ which react rapidly with $\mathrm{OH}$ (Wang et al., 1998; Lawrence et al., 1999; Lelieveld et al., 2002).

The INTEX-A campaign (Ren et al., 2008) was conducted over continental North America and the western Atlantic Ocean, covering a range of environments and chemical regimes. Model calculations for INTEX-A (Ren et al., 2008) show good agreement for $\mathrm{OH}$ in the continental planetary boundary at low isoprene concentrations $(<0.1 \mathrm{ppb})$, but display significant deviations from the observations when isoprene concentrations are high (upto and greater than $2 \mathrm{ppb}$ ), leading to the suggestion that there may be additional unknown $\mathrm{HO}_{\mathrm{x}}$ sources in forested regions.

Measurements made during the GABRIEL project in Amazonia (Martinez et al., 2010) also found much higher $\mathrm{OH}$ concentrations over tropical forests than predicted by model simulations (Lelieveld et al., 2008). Observations of $\mathrm{HO}_{2}$ were also found to be higher than model predictions during GABRIEL, although not to the same extent as for $\mathrm{OH}$. At the highest isoprene concentration observed $(6 \mathrm{ppb})$ the modelled $\mathrm{HO}_{2}$ was a factor of approximately 10 too low, compared to a factor of approximately 20 for $\mathrm{OH}$. Such results led to the proposal for a novel mechanism for $\mathrm{OH}$ recycling in isoprene oxidation, in which the $\mathrm{OH}$ initiated oxidation of isoprene results in reformation of $\mathrm{OH}$ through subsequent reactions of $\mathrm{HO}_{2}$ with $\mathrm{RO}_{2}$ species, leading to marked improvements in the model simulations (Lelieveld et al., 2008; Kubistin et al., 2008; Butler et al., 2008). It was proposed that recycling of $\mathrm{OH}$ in such reactions is masked in regions with high $\mathrm{NO}_{\mathrm{x}}$ due to competition for reaction with $\mathrm{HO}_{2}$ between $\mathrm{RO}_{2}$ and $\mathrm{NO}$, and is only apparent in regions with a combination of low $\mathrm{NO}_{\mathrm{x}}$ and high VOC concentrations such as Amazonia, where the mean NO concentration in the forest boundary layer during GABRIEL was $(10 \pm 10)$ ppt (Lelieveld et al., 2008).

Hofzumahaus et al. (2009) were also unable to explain $\mathrm{OH}$ measurements made in the Pearl River Delta, China, with $\mathrm{OH}$ concentrations in the afternoon 3 to 5 times higher than expected by the model. Measurements of $\mathrm{HO}_{2}$, however, were at most only approximately 1.3 times higher than expected, and similarly to $\mathrm{OH}$ only showed significant deviation from the model in the afternoon. While VOC concentrations in the Pearl River Delta were relatively high, with mean 
isoprene concentrations between 1 and $2 \mathrm{ppb}$, the $\mathrm{NO}_{\mathrm{x}}$ concentrations were significantly higher (mean noontime $\mathrm{NO} \sim$ $200 \mathrm{ppt}$ ) compared to those observed during GABRIEL. Similar model discrepancies for $\mathrm{OH}$ have also been found for the OP3 project in the Borneo rainforest (Hewitt et al., 2010; Pugh et al., 2010).

Our current understanding of $\mathrm{HO}_{\mathrm{x}}$ chemistry in regions with relatively low $\mathrm{NO}_{\mathrm{x}}$ and high biogenic emissions thus appears weak. It has been proposed that additional recycling of $\mathrm{HO}_{\mathrm{x}}$ occurs under such regimes through reactions of $\mathrm{RO}_{2}$ with $\mathrm{HO}_{2}$ and other $\mathrm{RO}_{2}$ radicals (Lelieveld et al., 2008). This provides an additional source of $\mathrm{HO}_{\mathrm{x}}$ that is masked in high $\mathrm{NO}_{\mathrm{x}}$ environments owing to the prevalence of $\mathrm{HO}_{2}+\mathrm{NO}$ and $\mathrm{RO}_{2}+\mathrm{NO}$ reactions (Lelieveld et al., 2008; Kubistin et al., 2008; Butler et al., 2008; Hofzumahaus et al., 2009). Several theoretical (Peeters et al., 2009; Da Silva et al., 2010) and laboratory studies (Hasson et al., 2004; Le Crane et al., 2006; Jenkin et al., 2007, 2008; Dillon and Crowley, 2008; Paulot et al., 2009) have now proposed mechanisms for additional $\mathrm{HO}_{\mathrm{x}}$ sources, largely based on $\mathrm{RO}_{2}$ radical chemistry, yet no definitive conclusions have been reached.

Measurements made during AMMA provide the first opportunity to investigate the processes controlling $\mathrm{HO}_{\mathrm{x}}$ over West Africa, and can be used to assess the significance of recent findings in $\mathrm{HO}_{\mathrm{x}}$ chemistry for this region.

In this paper we examine aircraft observations of $\mathrm{OH}$ and $\mathrm{HO}_{2}$ made in tropical West Africa (Commane et al., 2010) using a constrained box model in order to investigate the processes controlling the oxidising capacity in this region. We describe observations made over West Africa in Sect. 2, outline a $\mathrm{HO}_{\mathrm{x}}$ modelling framework based on constrained box modelling in Sect. 3, and describe the comparison between the modelled and measured $\mathrm{OH}$ and $\mathrm{HO}_{2}$ in Sects. 4 and 5, respectively. We also investigate the processes controlling the modelled $\mathrm{HO}_{\mathrm{x}}$, and compare the dominant processes influencing $\mathrm{HO}_{\mathrm{x}}$ over forest and Sahel regions in Sects. 5 and 6. Model sensitivity is discussed in Sect. 7 and conclusions are drawn in Sect. 8.

\section{AMMA}

The African Monsoon Multidisciplinary Analyses (AMMA) field campaign was a large international programme to look at a range of environmental issues in the West African region between 2005 and 2007 (Redelsperger et al., 2006; Lebel et al., 2010; Reeves et al., 2010; Mari et al., 2010). During the period between 17 July to 17 August 2006 the UK FAAM BAe146 research aircraft was stationed in Niamey, Niger, and undertook 21 flights from that base. The geographical extent of the flights is shown in Fig. 1. The aircraft flew in a range of environments, from the deserts in the north, through the Sahel, to the rainforests and ocean in the south. Air was also measured from the cities of Niamey and Lagos

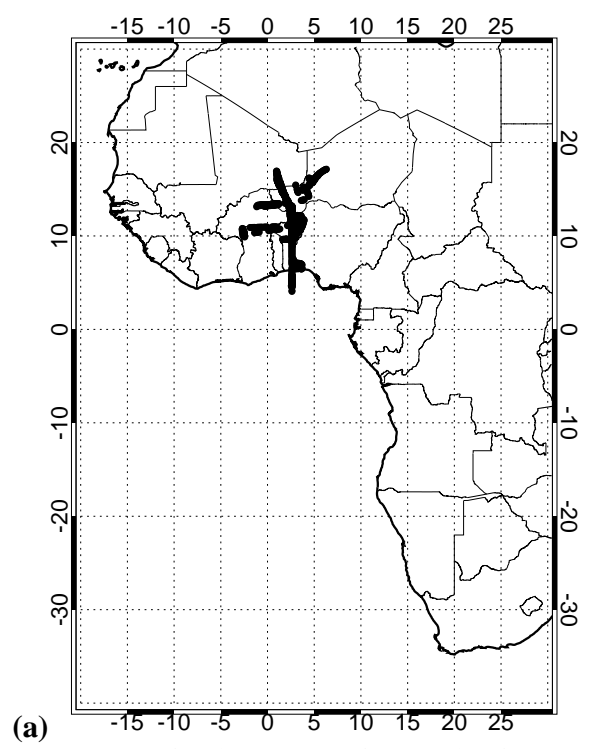

(a)

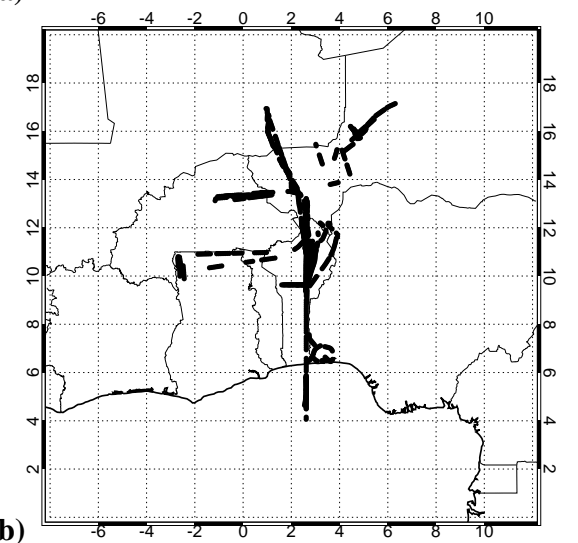

Fig. 1. Locations of the BAe146 aircraft during the AMMA campaign when $\mathrm{OH}$ or $\mathrm{HO}_{2}$ data are available, showing (a) the wider geographical area and (b) a close up of the region of interest.

(Hopkins et al., 2009). The aircraft was equipped to measure a number of atmospheric constituents (Reeves et al., 2010). Notably, this mission represents the first $\mathrm{HO}_{\mathrm{x}}$ measurements made over West Africa (Commane et al., 2010).

A range of papers have been written about the observations collected thus far (Redelsperger et al., 2006; Stewart et al., 2008; Capes et al., 2009; Hopkins et al., 2009; Lebel et al., 2010) and only brief descriptions of the measurement techniques are given here.

Ozone was measured using a TECO 49C UV absorption detector. Carbon monoxide measurements were made using an Aero Laser AL5002 Fast Carbon Monoxide Monitor (Gerbig et al., 1999). Non-methane hydrocarbons (NMHCs), volatile organic compounds (VOCs) and oxygenated volatile organic compounds (oVOCs) were measured by a combination of Proton Transfer Reaction Mass Spectrometry (PTRMS) (Murphy et al., 2010) and Gas Chromatography (GC) with a flame ionisation detector (Hopkins et al., 2006, 2009). 
For several NMHC/VOC species (acetone, isoprene and MVK/MACR) observations are available from both PTRMS and GC instruments, with measurements by PTRMS made approximately every $15 \mathrm{~s}$, while those by GC were made approximately every $15 \mathrm{~min}$ throughout the flight. The two instruments were in good agreement with each other for the species in common (acetone, isoprene and MVK/MACR) (Hopkins et al., 2009; Murphy et al., 2010).

$\mathrm{NO}_{\mathrm{x}}$ measurements were made by a chemiluminescence TECO $42 \mathrm{C}$ analyser with a heated molybdenum filament to enable conversion of $\mathrm{NO}_{2}$ to $\mathrm{NO}$. Additional $\mathrm{NO}_{\mathrm{x}}$ measurements were also made using a $\mathrm{NO}_{\mathrm{xy}}$ instrument on ten flights towards the end of the campaign (Brough et al., 2003; Stewart et al., 2008). The $\mathrm{NO}_{\mathrm{xy}}$ instrument measures the chemiluminescence from the reaction between $\mathrm{NO}$ and $\mathrm{O}_{3}$, and converts $\mathrm{NO}_{2}$ to $\mathrm{NO}$ by photolysis. The detection limits for the $\mathrm{NO}_{\mathrm{xy}}$ instrument are $3 \mathrm{ppt}$ for $\mathrm{NO}$ and $15 \mathrm{ppt}$ for $\mathrm{NO}_{2}$ at an averaging time of $10 \mathrm{~s}$, while those for the TECO $\mathrm{NO}_{\mathrm{x}}$ analyser are $2 \mathrm{ppb}$ for $30 \mathrm{~s}$ measurements and $50 \mathrm{ppt}$ for both species at an averaging time of $120 \mathrm{~s}$. While it has been shown that the total $\mathrm{NO}_{\mathrm{x}}$ measured by the two techniques are well correlated above $1 \mathrm{ppb}$ (Stewart et al., 2008), the TECO measurements are systematically higher than those obtained using the $\mathrm{NO}_{\mathrm{xy}}$ instrument, and the individual $\mathrm{NO}$ and $\mathrm{NO}_{2}$ measurements comprising the total $\mathrm{NO}_{\mathrm{x}}$ signals do not correlate well between the two instruments. Measurements from the $\mathrm{NO}_{\mathrm{xy}}$ instrument have been used in this work.

Measurements of formaldehyde were made using fluorescence techniques (Cardenas et al., 2000). Peroxy acetyl nitrate (PAN) was measured using gas chromatography with a two channel chromatograph coupled to a pair of electron capture detectors (Whalley et al., 2004). Carbon based adsorbent permeation tubes, with analysis using gas chromatography and detection using time of flight mass spectrometry (GC-TOFMS), were used on a number of flights during the campaign to measure monoterpene concentrations (Saxton et al., 2007; Capes et al., 2009). However, the time resolution of monoterpene measurements was low, and measurements were not made on all flights.

Total aerosol surface area was calculated using Mie Theory and scattering coefficients determined by a three wavelength integrating nephelometer (Anderson and Ogren, 1998; McNaughton et al., 2009).

Photolysis rates of $\mathrm{NO}_{2} \quad j\left(\mathrm{NO}_{2}\right)$ and $\mathrm{O}_{3} \quad j\left(\mathrm{O}^{1} \mathrm{D}\right)$ were measured by fixed bandwidth radiometry by the University of Leicester with $2 \times 2 \pi$-sr filter radiometers (Edwards and Monks, 2003; Bohn et al., 2008). For several flights the upwelling component to the $j\left(\mathrm{O}^{1} \mathrm{D}\right)$ signal has been estimated from the $j\left(\mathrm{NO}_{2}\right)$ signal owing to instrumental problems during the campaign (Brookes, 2009). As a result of the approximations made in estimation of the total $j\left(\mathrm{O}^{1} \mathrm{D}\right)$, including those made during calibration to account for the non-linearity of $j\left(\mathrm{O}^{1} \mathrm{D}\right)$ with total ozone column, temperature and solar zenith angle, there may be a systematic error in the $j\left(\mathrm{O}^{1} \mathrm{D}\right)$, requiring a potential reduction by $30 \%$
(Brookes, 2009). Sensitivity of the model to this potential systematic error is discussed in Sect. 7.

The focus of this paper is on the $\mathrm{OH}$ and $\mathrm{HO}_{2}$ observations. The AMMA campaign represents the first $\mathrm{HO}_{\mathrm{x}}$ field measurements obtained with the Leeds aircraft FAGE instrument. The instrument is described in detail by Commane et al. (2010) where an overview of the FAGE observations made during AMMA is also given. The measurements were made by Fluorescence Assay with Gas Expansion (FAGE) using low pressure Laser Induced Fluorescence (LIF) to detect the on-resonance fluorescence of $\mathrm{OH}$ at $308 \mathrm{~nm}$ (Heard and Pilling, 2003; Commane et al., 2010). A fluorescence cell with two sequential laser axes was used to monitor $\mathrm{OH}$ and $\mathrm{HO}_{2}$, with $\mathrm{HO}_{2}$ converted to $\mathrm{OH}$ by its reaction with $\mathrm{NO}$, enabling simultaneous detection of $\mathrm{OH}$ and $\mathrm{HO}_{2}$. Calibrations were performed before and after the campaign using water photolysis at $185 \mathrm{~nm}$ to produce a known amount of $\mathrm{HO}_{\mathrm{x}}$. The lamp flux was determined by NO actinometry (Commane et al., 2010). Uncertainties in the measurements resulting from the calibration procedure are estimated at $23 \%(1 \sigma)$.

The median limit of detection (LOD) for $\mathrm{OH}$ during AMMA was $7.1 \times 10^{5} \mathrm{~cm}^{-3}(1 \sigma)$ for a $60 \mathrm{~s}$ averaging period, close to ambient $\mathrm{OH}$ concentrations in the troposphere, resulting in many of the $\mathrm{OH}$ observations reported being close to or below the limit of detection and subject to large uncertainties. The detection limit is considerably higher than normally experienced for operation of the ground-based Leeds FAGE instrument (Smith et al., 2006), partly due to a lower precision caused by instabilities of the instrument when operated on the aircraft. Some of this instability was caused by temperature fluctuations inside the aircraft which resulted in changes of the timing between the laser pulse and the fluorescence detection (Commane et al., 2010). The poorer precision had the greatest impact on $\mathrm{OH}$ measurements as the signal and background signals are similar to one another. The median LOD for $\mathrm{HO}_{2}$ was $7.5 \times 10^{5} \mathrm{~cm}^{-3}(1 \sigma)$, two orders of magnitude less than ambient $\mathrm{HO}_{2}$ concentrations, resulting in very few measurements being below the LOD, in contrast to $\mathrm{OH}$. Hence the $\mathrm{HO}_{2}$ measurements were much less sensitive to any instabilities in the timing of the fluorescence detection.

\section{Model approach}

In order to interpret the observations a box model is used. Model calculations were made using the Dynamically Simple Model of Atmospheric Chemical Complexity (DSMACC) (Emmerson and Evans, 2009). DSMACC is a flexible zero-dimensional box model using the Kinetic PreProcessor (KPP) (Sandu et al., 2006).

Simulations presented here used an observationally constrained version, with the chemistry scheme generated by the Master Chemical Mechanism (MCM) (Saunders et al., 
2003; Jenkin et al., 2003). The MCM contains near explicit degradation schemes for 135 volatile organic compounds in the troposphere, resulting in over 5600 species and 13500 reactions and representing a detailed and comprehensive chemistry scheme for tropospheric composition modelling. Rate coefficients for inorganic reactions and three body reactions were updated to recent recommendations (Atkinson et al., 2004; Sander et al., 2006). For these simulations the chemistry of the degradation of ethane, propane, iso-butane, $n$-butane, ethene, propene, acetylene, isoprene, methanol, ethanol, acetone, methyl ethyl ketone (MEK), methyl vinyl ketone (MVK) and methacrolein (MACR) is used. For all species a physical first order removal reaction was also included. This could be considered as a continuous deposition processes (such as dry deposition or a continuous wet deposition). The default value of the first order rate coefficient for the loss process is $1 \times 10^{-5} \mathrm{~s}^{-1}$, giving a lifetime of approximately 1 day. Model results were not found to be strongly dependent on the rate of the deposition process. Sensitivity to this is described in Sect. 7.

Loss of $\mathrm{OH}$ and $\mathrm{HO}_{2}$ onto aerosol surfaces was represented in the model by inclusion of a first-order process, using the uptake coefficients $\gamma=1.0$ for $\mathrm{OH}$ and $\gamma=0.1$ for $\mathrm{HO}_{2}$ (Ravishankara et al., 1997; Thornton et al., 2008; Whalley et al., 2010).

The model follows the approach of Olson et al. (2004, 2006). For each observation of $\mathrm{OH}$ or $\mathrm{HO}_{2}$ the objective is to calculate an expected value from the other parameters measured on board the aircraft and the chemical scheme used. All aircraft parameters are merged onto a $60 \mathrm{~s} \mathrm{time-}$ base for expediency. For each observed time point, those species which have not been observed are set initially to zero. Those species which have been observed are set initially to the observed value and kept constant. The model is integrated forward in time with diurnally varying photolysis rates until a diurnal steady state is reached. Diurnal steady state is reached when the daily mean fractional change in the concentration of each unobserved species and the daily mean fractional change in the sum of all species concentrations between a day and the previous day is less than 0.01 .

$$
\frac{1}{N_{\mathrm{S}} \cdot N_{\mathrm{T}}} \sum_{i=1}^{N_{\mathrm{S}}} \sum_{j=1}^{N_{\mathrm{T}}} \frac{\left[\mathrm{X}_{i}\right]^{n, j}-\left[\mathrm{X}_{i}\right]^{n-1, j}}{\left[\mathrm{X}_{i}\right]^{n, j}} \leq 0.01
$$

where $N_{\mathrm{S}}$ is the number of species being integrated forwards, $N_{\mathrm{T}}$ is the number of integration time steps in a day, $\left[\mathrm{X}_{i}\right]^{n, j}$ is the mixing ratio of species $i$, during the $j^{\text {th }}$ time step on day $n$. Once a diurnal steady state solution has been found the model outputs the concentration of all species so they can be compared to observations.

Thus unobserved species are considered to be at their diurnal steady state concentration. The impact of this approximation on $\mathrm{HO}_{\mathrm{x}}$ is considered in Sects. 5 and 6, where the processes controlling $\mathrm{HO}_{\mathrm{x}}$ in the model are examined.
The model uses the TUV radiation model (v4.2) to calculate diurnally varying photolysis rates for clear sky conditions. An ozone column of 260 Dobson units was assumed (TOMS satellite data, http://toms.gsfc.nasa.gov/ ozone/ozone_v8.html). Instead of performing the radiation calculation for each integration time point, the calculation was performed for solar zenith angles between $0^{\circ}$ and $90^{\circ}$ in $5^{\circ}$ steps. As the integration occurred and time incremented forwards the solar zenith angle was calculated and the photolysis rates found from spline fitting. Correction factors (due to cloud, albedo etc.) for $j\left(\mathrm{O}^{1} \mathrm{D}\right)$ and $j\left(\mathrm{NO}_{2}\right)$ are calculated from the ratio of the observed and simulated photolysis rates, with the correction factor for $j\left(\mathrm{NO}_{2}\right)$ being applied to all photolysis reactions other than $\mathrm{O}_{3} \rightarrow \mathrm{O}\left({ }^{1} \mathrm{D}\right)+\mathrm{O}_{2}$. These photolysis correction factors are calculated for each observation point and applied for the integration forwards to diurnal steady state.

The concentrations of oxides of nitrogen are treated differently to other species. Over an individual $24 \mathrm{~h}$ period in the model the concentration of total $\mathrm{NO}_{\mathrm{x}}$ (defined as $\left.\mathrm{NO}+\mathrm{NO}_{2}+\mathrm{NO}_{3}+2 \mathrm{~N}_{2} \mathrm{O}_{5}+\mathrm{HONO}+\mathrm{HNO}_{4}\right)$ is kept constant. The concentration of an individual $\mathrm{NO}_{\mathrm{x}}$ species varies due to changes in photolysis rates etc. At the end of each $24 \mathrm{~h}$ period the calculated concentration of one individual $\mathrm{NO}_{\mathrm{x}}$ species (typically either $\mathrm{NO}$ or $\mathrm{NO}_{2}$ ) is compared to the equivalent measured concentration and the concentration of all $\mathrm{NO}_{\mathrm{x}}$ species is fractionally increased or decreased so that the measured and the modelled concentrations of the observed species match. As the model simulation runs forwards and a diurnal steady state is reached the fractional change in $\mathrm{NO}_{\mathrm{x}}$ becomes increasingly smaller.

To be modelled, time points needed to have observations of $\mathrm{OH}$ or $\mathrm{HO}_{2}$ together with the physical state (latitude, longitude, pressure, temperature and water vapour) and observations of $\mathrm{CO}, \mathrm{O}_{3}, \mathrm{NO}, j\left(\mathrm{O}^{1} \mathrm{D}\right)$ and $j\left(\mathrm{NO}_{2}\right)$. Since the TECO $\mathrm{NO}_{\mathrm{x}}$ instrument is known to be the less sensitive instrument, with possible interferences from $\mathrm{NO}_{\mathrm{z}}$ in the $\mathrm{NO}_{2}$ measurement (Stewart et al., 2008), the $\mathrm{NO}_{\mathrm{xy}} \mathrm{NO}_{\mathrm{x}}$ measurements are considered to be the more reliable. Model input for $\mathrm{NO}_{\mathrm{x}}$ has therefore been restricted to the $\mathrm{NO}_{\mathrm{xy}}$ measurements. Concentrations of methane and hydrogen were kept constant at values of $1770 \mathrm{ppm}$ (SCIAMACHY Satellite Data, http://www.iup. uni-bremen.de/sciamachy/NIR_NADIR_WFM_DOAS/) and 550 ppm (Ehhalt and Roher, 2009; Novelli et al., 1999), respectively. Where ethane, propane, iso-butane, $n$-butane, ethene, propene, acetylene, methanol, ethanol, acetone, formaldehyde, acetaldehyde, peroxy acetyl nitrate (PAN), methyl ethyl ketone (MEK), isoprene, methyl vinyl ketone (MVK) and methacrolein (MACR) were available they were also included. PTRMS measurements have been used where available due to the greater time resolution of the technique compared to GC measurements. Monoterpenes have not been included in standard model runs since measurements were not made on all flights and time resolution of 
Table 1. Parameters used to fit hydrocarbon data as a function of the CO concentration. Hydrocarbon concentrations were used in ppt, while CO concentrations were in ppb. RMS refers to the root mean square difference between the observed and calculated values.

\begin{tabular}{llll}
\hline Hydrocarbon/ppt & Linear regression & $r^{2}$ & RMS $/ \mathrm{ppt}$ \\
\hline Ethane & $(5.08 \times[\mathrm{CO}] / \mathrm{ppb})+153.05$ & 0.737 & 4.73 \\
Propane & $(0.91 \times[\mathrm{CO}] / \mathrm{ppb})-40.43$ & 0.631 & 1.09 \\
iso-butane & $(0.77 \times[\mathrm{CO}] / \mathrm{ppb})-64.96$ & 0.268 & 1.98 \\
$n$-butane & $(2.02 \times[\mathrm{CO}] / \mathrm{ppb})-189.47$ & 0.315 & 4.68 \\
Ethene & $(4.71 \times[\mathrm{CO}] / \mathrm{ppb})-408.46$ & 0.426 & 8.55 \\
Propene & $(1.02 \times[\mathrm{CO}] / \mathrm{ppb})-88.98$ & 0.362 & 2.10 \\
Acetylene & $(7.03 \times[\mathrm{CO}] / \mathrm{ppb})-572.09$ & 0.619 & 8.53 \\
\hline
\end{tabular}

Table 2. Summary of data inputs to the model. Chemical names are those used in the MCM.

\begin{tabular}{|c|c|c|c|c|}
\hline Species & Median & Mean & $\begin{array}{l}\text { Standard } \\
\text { deviation }\end{array}$ & Range \\
\hline $\mathrm{O}_{3} / \mathrm{ppb}$ & 41.5 & 42.6 & 16.9 & 11.2 to 114.5 \\
\hline $\mathrm{CO} / \mathrm{ppb}$ & 94.4 & 103.9 & 35.5 & 64.0 to 312.6 \\
\hline $\mathrm{H}_{2} \mathrm{O} / \mathrm{ppm}$ & 10833.0 & 14182.3 & 10386.3 & 565.9 to 30091.0 \\
\hline $\mathrm{NO} / \mathrm{ppt}$ & 50.9 & 66.2 & 58.6 & 0.3 to 525.5 \\
\hline $\mathrm{HCHO} / \mathrm{ppt}$ & 300.9 & 384.9 & 399.3 & 0 to 3246.7 \\
\hline $\mathrm{C}_{2} \mathrm{H}_{6} / \mathrm{ppt}$ & 628.9 & 674.6 & 176.3 & 403.2 to 1620.1 \\
\hline $\mathrm{C}_{3} \mathrm{H}_{8} / \mathrm{ppt}$ & 44.4 & 54.2 & 36.6 & 7.8 to 326.4 \\
\hline iso- $\mathrm{C}_{4} \mathrm{H}_{10} / \mathrm{ppt}$ & 6.2 & 21.1 & 67.8 & 0 to 873.4 \\
\hline$n-\mathrm{C}_{4} \mathrm{H}_{10} / \mathrm{ppt}$ & 3.8 & 39.5 & 132.2 & 0 to 1607.0 \\
\hline $\mathrm{C}_{2} \mathrm{H}_{4} / \mathrm{ppt}$ & 26.8 & 101.8 & 216.4 & 0 to 1619.1 \\
\hline $\mathrm{C}_{3} \mathrm{H}_{6} / \mathrm{ppt}$ & 5.5 & 20.5 & 41.7 & 0 to 307.4 \\
\hline $\mathrm{C}_{5} \mathrm{H}_{8} / \mathrm{ppt}$ & 23.1 & 104.0 & 239.1 & 0 to 2026.2 \\
\hline $\mathrm{CH}_{3} \mathrm{OH} / \mathrm{ppt}$ & 0 & 652.6 & 6372.9 & 0 to 101230.0 \\
\hline $\mathrm{CH}_{3} \mathrm{COCH}_{3} / \mathrm{ppt}$ & 951.2 & 896.6 & 307.2 & 0 to 2833.9 \\
\hline $\mathrm{MEK} / \mathrm{ppt}$ & 0 & 60.3 & 364.0 & 0 to 6483.2 \\
\hline MVK/ppt & 4.3 & 56.7 & 115.7 & 0 to 623.3 \\
\hline MACR/ppt & 1.9 & 25.5 & 52.0 & 0 to 280.0 \\
\hline PAN/ppt & 8.0 & 49.8 & 91.1 & 0 to 633.0 \\
\hline $\mathrm{C}_{2} \mathrm{H}_{2} / \mathrm{ppt}$ & 94.8 & 177.2 & 299.7 & 0 to 2618.6 \\
\hline
\end{tabular}

the measurements is not as great as those for PTRMS or GC measurements. Model sensitivity to monoterpenes is discussed separately in Sect. 7.

In order to maximise the number of points in the model, for data points where measurements of VOCs were not available, parameterised alkane/alkene concentrations as a linear function of the $\mathrm{CO}$ concentration were used. Table 1 shows the fitting parameters used in this procedure, with typical fits given in Fig. 2. A summary of inputs to the model is given in Table 2.

Data from flight B228 have not been included in the model due to large differences between the observed photolysis rates and those calculated by TUV for a number of data points on this flight. The mean ratio of observed $j\left(\mathrm{O}^{1} \mathrm{D}\right)$ to TUV calculations was $(0.83 \pm 0.28)$ for all flights excluding B228, while there were a significant number of data points during B228 with $j\left(\mathrm{O}^{1} \mathrm{D}\right)$ ratios exceeding 1.5.

\section{Observations and general model performance for $\mathrm{OH}$}

Figure 3 shows the comparison between the modelled and measured $\mathrm{OH}$. Although there are some points where there is good model agreement, in general the model provides a systematic overestimate of $\mathrm{OH}$ for much of the atmosphere, with a best-fit gradient of 2.5. While some high $\mathrm{OH}$ concentrations were observed (Commane et al., 2010), the highest observed concentrations have not been included in this study due to the lack of supporting measurements. This model overestimate is not consistent with previous studies (Ren et al., 2008; Lelieveld et al., 2008; Hofzumahaus et al., 2009). However, as discussed above, and described in detail by Commane et al. (2010), instrumental instabilities led to an increased instrumental limit of detection for $\mathrm{OH}$, and lower confidence in the measurements. 


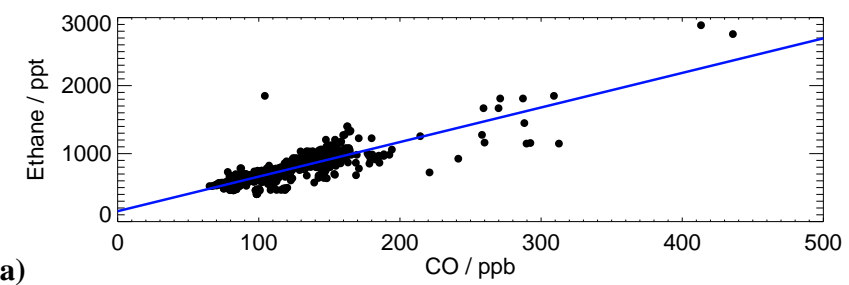

(a)

(b)

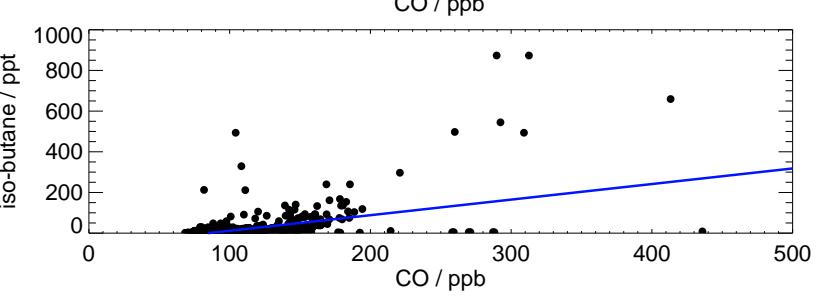

Fig. 2. (a) Observed ethane concentrations as a function of $\mathrm{CO}$, $r^{2}=0.737$ and (b) observed iso-butane concentrations as a function of $\mathrm{CO}, r^{2}=0.268$. The best fit lines are given in blue.

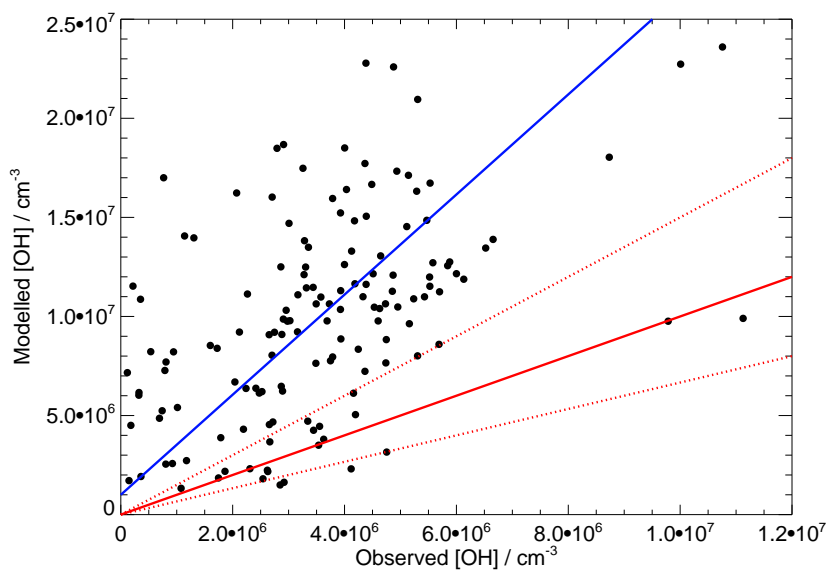

Fig. 3. Comparison between modelled and observed $\mathrm{OH}$ concentrations. The 1:1 line is shown by the solid red line, with dashed red lines indicating 50\% limits on the 1:1 line. The best fit to the data is given in blue and is described by $y=(2.53 \pm 0.43) x+\left[(1.00 \pm 1.60) \times 10^{6}\right]$, with $r^{2}=0.75$.

In order to reduce the modelled $\mathrm{OH}$ to levels similar to the observed values it is necessary to increase the $\mathrm{CO}$ concentration by an order of magnitude, or reduce the concentrations of $\mathrm{O}_{3}, \mathrm{H}_{2} \mathrm{O}$ vapour or $\mathrm{NO}$ by an order of magnitude. Such changes to the input parameters are greater than could be reasonable based on the expected observational errors and detection limits for these species, and adversely affect the model agreement observed for $\mathrm{HO}_{2}$ (Sect. 4.2), suggesting that the discrepancy between modelled and observed $\mathrm{OH}$ may result from experimental difficulties associated with the measurement of $\mathrm{OH}$. Given this result, it has not been possible to investigate the $\mathrm{OH}$ chemistry using the AMMA dataset and we concentrate on understanding the $\mathrm{HO}_{2}$ observations, where the experimental signals are much larger and well above the detection limits.

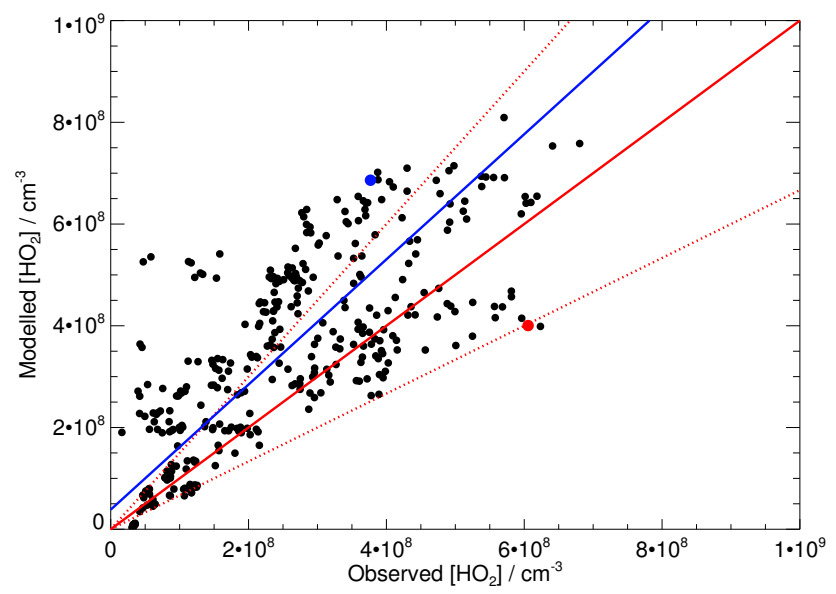

Fig. 4. Comparison between modelled and observed $\mathrm{HO}_{2}$ concentrations. The 1:1 line is shown by the solid red line, with dashed red lines indicating $50 \%$ limits on the $1: 1$ line. The best fit to the data is given in blue and is described by $y=(1.23 \pm 0.11) x+\left[(3.85 \pm 3.06) \times 10^{7}\right]$, with $r^{2}=0.75$. The data point in red marks the single point referred to in Sect. 4.2.1 for which the sensitivity to isoprene and $\mathrm{NO}_{\mathrm{x}}$ was investigated and used to represent the midday forest boundary layer referred to in Sect. 4.3 and Fig. 7. The data point in blue marks the single point used to represent the midday Sahel boundary layer referred to in Sect. 4.3 and Fig. 10.

\section{Observations and general model performance for $\mathrm{HO}_{2}$}

Figure 4 shows the scatterplot of modelled to observed $\mathrm{HO}_{2}$ concentrations. The best fit line between the model and the observations is given by $\left[\mathrm{HO}_{2}\right]_{\text {mod }}=(1.23 \pm 0.11)\left[\mathrm{HO}_{2}\right]_{\mathrm{obs}}+(3.85 \pm 3.06) \times 10^{7}$ with a correlation coefficient squared of 0.75 . This is just within the calibration uncertainty of the measurements (approximately $23 \%$ at the $1 \sigma$ level) (Commane et al., 2010). The model was thus capable of reproducing much of the trends and variability in the observed $\mathrm{HO}_{2}$, although there is in general an overestimation of $\mathrm{HO}_{2}$.

While model performance could be considered good it is not altogether surprising. Assuming simple photochemistry, most of the $\mathrm{HO}_{\mathrm{x}}$ production should be due to the reaction between $\mathrm{O}\left({ }^{1} \mathrm{D}\right)$ (produced by $\mathrm{O}_{3}$ photolysis) and $\mathrm{H}_{2} \mathrm{O}$ vapour, and most of the $\mathrm{HO}_{\mathrm{x}}$ loss should be due to the $\mathrm{HO}_{2}$ self-reaction. Thus at steady state the $\mathrm{HO}_{2}$ concentration, $\left[\mathrm{HO}_{2}\right]_{\mathrm{ss}}$, can be determined by a consideration of the rates of reactions below, and is thus given by Eq. (2).

$$
\begin{aligned}
& \mathrm{O}\left({ }^{1} \mathrm{D}\right)+\mathrm{H}_{2} \mathrm{O} \longrightarrow 2 \mathrm{OH} \\
& \mathrm{O}\left({ }^{1} \mathrm{D}\right)+\mathrm{N}_{2} \longrightarrow+\mathrm{O}\left({ }^{3} \mathrm{P}\right)+\mathrm{N}_{2} \\
& \mathrm{O}\left({ }^{1} \mathrm{D}\right)+\mathrm{O}_{2} \longrightarrow+\mathrm{O}\left({ }^{3} \mathrm{P}\right)+\mathrm{O}_{2} \\
& \mathrm{HO}_{2}+\mathrm{HO}_{2}(+\mathrm{M}) \longrightarrow \mathrm{H}_{2} \mathrm{O}_{2}+\mathrm{O}_{2}(+\mathrm{M})
\end{aligned}
$$




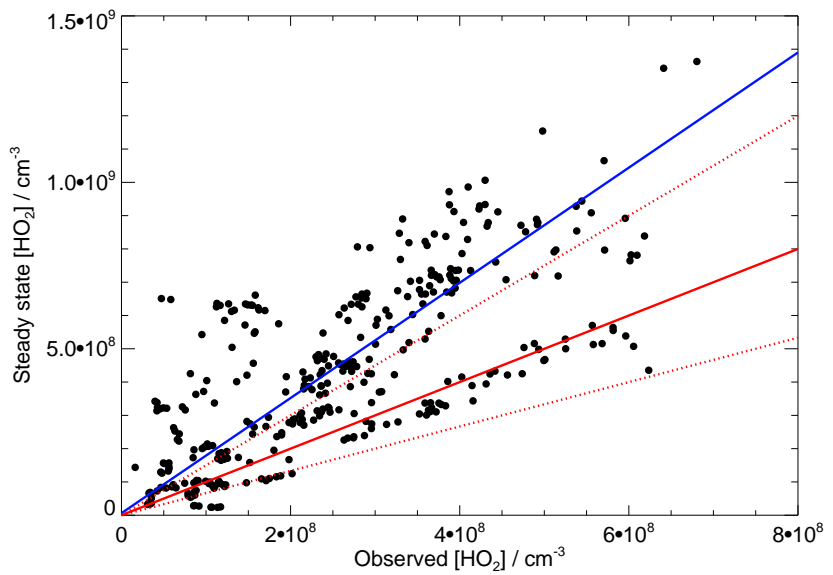

Fig. 5. Comparison between observed $\mathrm{HO}_{2}$ concentrations and a simple steady state model. The 1:1 line is shown by the solid red line, with dashed red lines indicating $50 \%$ limits on the $1: 1$ line. The best fit to the data is given in blue and is described by $y=(1.73 \pm 0.16) x\left[+(0.62 \pm 4.33) \times 10^{7}\right]$, with $r^{2}=0.74$. While the apparent separation of the data into two regimes does correspond to data points with high isoprene and those with low isoprene, discrimination on the basis of geography is not possible since both regimes contain a mixture of boundary layer and free troposphere data points over both forest and Sahel.

$\left[\mathrm{HO}_{2}\right]_{\mathrm{ss}}=\sqrt{\frac{2 j\left(\mathrm{O}^{1} \mathrm{D}\right)\left[\mathrm{O}_{3}\right] F_{\mathrm{OH}}}{2 k_{\left(\mathrm{HO}_{2}+\mathrm{HO}_{2}\right)}}}$

where $F_{\mathrm{OH}}$ represents the fraction of $\mathrm{O}\left({ }^{1} \mathrm{D}\right)$ reacting with $\mathrm{H}_{2} \mathrm{O}$ to form $2 \mathrm{OH}$ rather than being quenched (Eq. 3).

$F_{\mathrm{OH}}=\frac{k_{\left(\mathrm{H}_{2} \mathrm{O}+\mathrm{O}^{1} \mathrm{D}\right)}\left[\mathrm{H}_{2} \mathrm{O}\right]}{k_{\left(\mathrm{H}_{2} \mathrm{O}+\mathrm{O}^{1} \mathrm{D}\right)}\left[\mathrm{H}_{2} \mathrm{O}\right]+k_{\left(\mathrm{N}_{2}+\mathrm{O}^{1} \mathrm{D}\right)}\left[\mathrm{N}_{2}\right]+k_{\left(\mathrm{O}_{2}+\mathrm{O}^{1} \mathrm{D}\right)}\left[\mathrm{O}_{2}\right]}$

Using this simple relationship on the dataset gives the calculated steady state $\mathrm{HO}_{2}$ shown in Fig. 5. The best fit line between the calculated steady state $\mathrm{HO}_{2}$ and the observations is given by $\left[\mathrm{HO}_{2}\right]_{\mathrm{ss}}=(1.73 \pm 0.16)\left[\mathrm{HO}_{2}\right]_{\mathrm{obs}}-(0.62 \pm 4.33) \times 10^{7}$ with a correlation coefficient squared of 0.74 , showing that much of the photochemistry determining $\mathrm{HO}_{2}$ concentrations during AMMA was indeed dominated by relatively simple processes and that almost all the variability in $\mathrm{HO}_{2}$ is driven by photolysis rates and concentrations of water and ozone. There are, however, significant $\mathrm{HO}_{2}$ sinks missing from the steady state model. In the full DSMACC model run the additional sinks are due to $\mathrm{HO}_{2}+\mathrm{RO}_{2}$ reactions.

\subsection{Impact of isoprene}

The model agreement for $\mathrm{HO}_{2}$ during AMMA (Fig. 4) appears somewhat contradictory to recent studies discussed in the introduction which imply a significant lack of understanding of $\mathrm{HO}_{\mathrm{x}}$ chemistry in forested areas with high isoprene and low $\mathrm{NO}_{\mathrm{x}}$ levels (Ren et al., 2008; Lelieveld et al., 2008).

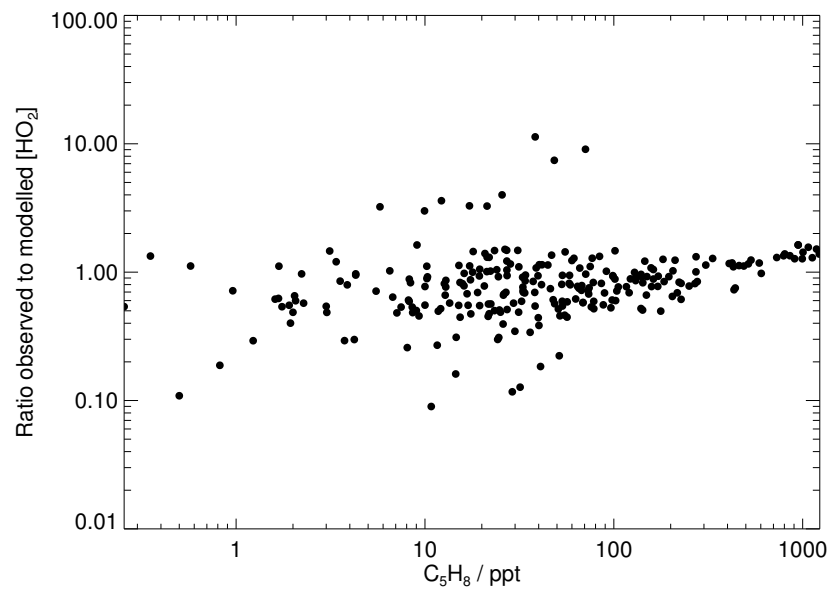

Fig. 6. Model success (ratio of observed $\mathrm{HO}_{2}$ to modelled $\mathrm{HO}_{2}$ ) as a function of isoprene concentration for the base model run, $r^{2}=0.32$.

Figure 6 shows the model success (Eq. 4) as a function of isoprene concentration for this study. Although there is some indication of model underestimation at high isoprene (ratio of observed to modelled $\mathrm{HO}_{2}$ of $\sim 1.5$ ), the underestimation is small compared to that observed during GABRIEL where a ratio observed to modelled $\mathrm{HO}_{2}$ of approximately 7 was observed in the boundary layer in the afternoon, with a ratio between 3 and 5 at isoprene concentrations comparable to those observed during AMMA (Kubistin et al., 2008).

$$
\frac{\left[\mathrm{HO}_{2}\right]_{\mathrm{obs}}}{\left[\mathrm{HO}_{2}\right]_{\bmod }}
$$

In order to further assess the processes controlling $\mathrm{HO}_{2}$, and the effects of isoprene, we have selected a single time point from the dataset corresponding to a measurement taken at 13:53 GMT on day 229 in the forest boundary layer (latitude $10.13^{\circ} \mathrm{N}$, longitude $2.69^{\circ} \mathrm{E}$, pressure $951.5 \mathrm{hPa}$ ) and conducted sensitivity tests to the isoprene and NO concentrations. The data point has a relatively high concentration of isoprene (1184 ppt compared to the mean of $294 \mathrm{ppt}$ and standard deviation $333 \mathrm{ppt}$ over the forest boundary layer) and a relatively low NO concentration of $51 \mathrm{ppt}$ (compared to the mean of $59 \mathrm{ppt}$ and standard deviation $30 \mathrm{ppt}$ over the forest boundary layer). Figure 4 shows the data point in red on the $\mathrm{HO}_{2}$ model to observation scatterplot. Concentrations of measured species for this point are listed in Table 3.

Figure 7 shows the instantaneous $\mathrm{RO}_{\mathrm{x}}\left(\left[\mathrm{RO}_{\mathrm{x}}\right]=[\mathrm{OH}]+\right.$ $\left.\left[\mathrm{HO}_{2}\right]+\left[\mathrm{RO}_{2}\right]+[\mathrm{RO}]\right), \mathrm{HO}_{\mathrm{x}}$ and $\mathrm{HO}_{2}$ budgets calculated for this point. Production of radicals (Fig. 7a) is dominated by ozone photolysis, followed by photolysis of formaldehyde (HCHO) and methylglyoxal (MGLYOX). The model is constrained with observations of both $\mathrm{O}_{3}$ and $\mathrm{HCHO}$. Both formaldehyde and methylglyoxal are oxidation products of isoprene, as are several of the principal species photolysed to produce $\mathrm{RO}_{\mathrm{x}}$. Radical loss is dominated by peroxide 
Table 3. Model inputs for the single points over the forest and Sahel used to investigate the sensitivity of the modelled $\mathrm{HO}_{2}$ to isoprene and $\mathrm{NO}_{\mathrm{x}}$ concentrations and to investigate the processes controlling the chemistry of the forest and Sahel. For investigation of the sensitivity of the modelled $\mathrm{HO}_{2}$ to isoprene and $\mathrm{NO}_{\mathrm{x}}$ concentrations the data point over the forest was used, with isoprene and $\mathrm{NO}_{\mathrm{x}}$ concentrations as shown in Fig. 9. Chemical names are those used in the MCM.

\begin{tabular}{lrr}
\hline Parameter & Forest & Sahel \\
\hline Latitude/deg & 10.13 & 14.48 \\
Longitude/deg & 2.69 & 4.35 \\
Pressure/hPa & 951.5 & 961.3 \\
Temperature/K & 299.1 & 299.7 \\
$\mathrm{O}_{3} / \mathrm{ppb}$ & 20.6 & 40.3 \\
$\mathrm{CO} / \mathrm{ppb}$ & 148.2 & 87.2 \\
$\mathrm{H}_{2} \mathrm{O} / \mathrm{ppm}$ & 27959 & 25797 \\
$j\left(\mathrm{O}^{1} \mathrm{D}\right) / 10^{-5} \mathrm{~s}^{-1}$ & 3.5 & 3.4 \\
$j(\mathrm{NO} 2) / 10^{-3} \mathrm{~s}^{-1}$ & 7.6 & 7.9 \\
$\mathrm{C}_{2} \mathrm{H}_{6} / \mathrm{ppt}$ & 906.8 & 596.7 \\
$\mathrm{C}_{3} \mathrm{H}_{8} / \mathrm{ppt}$ & 95.1 & 39.4 \\
$i s o-\mathrm{C}_{4} \mathrm{H}_{10} / \mathrm{ppt}$ & 48.7 & 19.0 \\
$n-\mathrm{C}_{4} \mathrm{H}_{10} / \mathrm{ppt}$ & 10.9 & 0 \\
$\mathrm{C}_{2} \mathrm{H}_{4} / \mathrm{ppt}$ & 289.4 & 2.3 \\
$\mathrm{C}_{3} \mathrm{H}_{6} / \mathrm{ppt}$ & 61.8 & 0 \\
$\mathrm{C}_{2} \mathrm{H}_{2} / \mathrm{ppt}$ & 469.4 & 40.9 \\
$\mathrm{C}_{5} \mathrm{H}_{8} / \mathrm{ppt}$ & 1183.8 & 0 \\
$\mathrm{NO}_{\mathrm{O}} / \mathrm{ppt}$ & 51.5 & 10.3 \\
\hline
\end{tabular}

formation from $\mathrm{HO}_{2}+\mathrm{RO}_{2}$ and $\mathrm{HO}_{2}+\mathrm{HO}_{2}$, with reaction of $\mathrm{HO}_{2}$ and isoprenyl peroxy radicals $\left(\mathrm{ISOPO}_{2}\right.$, of which there are four isomers in the $\mathrm{MCM}$ ) constituting the major radical loss process.

Diagnosing the $\mathrm{HO}_{\mathrm{x}}$ budget (Fig. 7b) shows that while $\mathrm{OH}+\mathrm{C}_{5} \mathrm{H}_{8}$ and $\mathrm{HO}_{2}+\mathrm{ISOPO}_{2}$ are dominant $\mathrm{HO}_{\mathrm{x}}$ sinks, there is significant production of $\mathrm{HO}_{\mathrm{x}}$ from decomposition of isoprenyl alkoxy radicals (ISOPO), which not only produce $\mathrm{HO}_{2}$ directly but also produce aldehyde species (HCHO, $\mathrm{HC} 4 \mathrm{ACHO}$ and $\mathrm{HC} 4 \mathrm{CCHO}$, capitalised species names are those used in the MCM) which photolyse to generate further $\mathrm{HO}_{2}$. There is also significant production of $\mathrm{HO}_{\mathrm{x}}$ from $\mathrm{CH}_{3} \mathrm{O}$, produced mainly by reaction of $\mathrm{NO}$ with $\mathrm{CH}_{3} \mathrm{O}_{2}$, which is derived from oxidation of both methane and isoprene.

If there is to be a net sink of $\mathrm{HO}_{\mathrm{x}}$ resulting from $\mathrm{OH}+$ isoprene then isoprenyl peroxy radicals $\left(\mathrm{ISOPO}_{2}\right)$ must react predominantly with $\mathrm{HO}_{2}$ to produce peroxides. However, at the $\mathrm{NO}_{\mathrm{x}}$ levels encountered over the forest boundary layer during AMMA $([\mathrm{NO}]=(59 \pm 30) \mathrm{ppt})$ the reactions of $\mathrm{ISOPO}_{2}$ with NO compete efficiently (70\%) with those of $\mathrm{ISOPO}_{2}$ with $\mathrm{HO}_{2}$, providing a means of generating ISOPO radicals and ultimately $\mathrm{HO}_{2}$ through subsequent chemistry, thereby helping to conserve the total $\mathrm{HO}_{\mathrm{x}}$ radical budget. A generalised chemical scheme for these processes is depicted in Fig. 8.

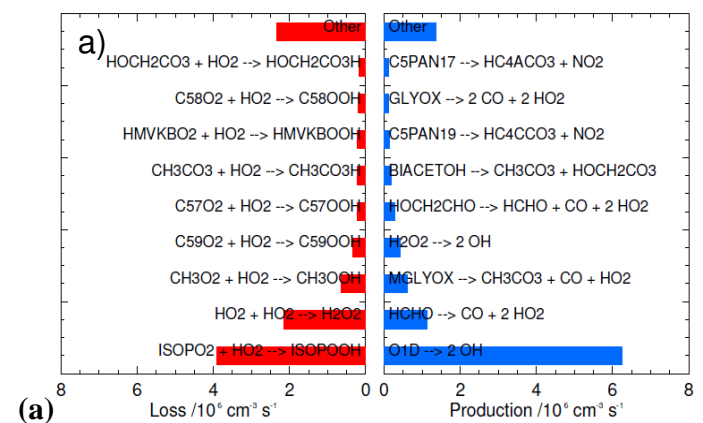

(a)

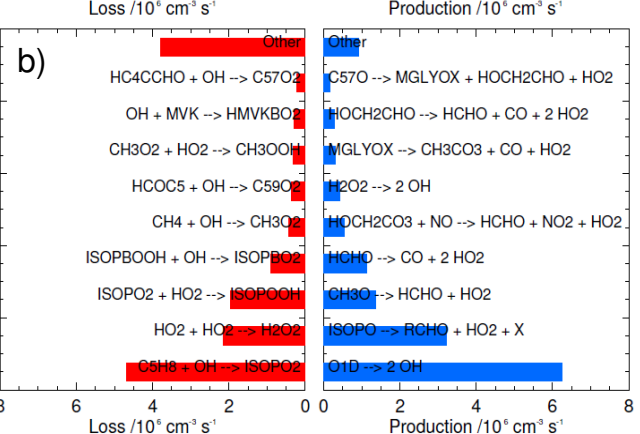

(b)

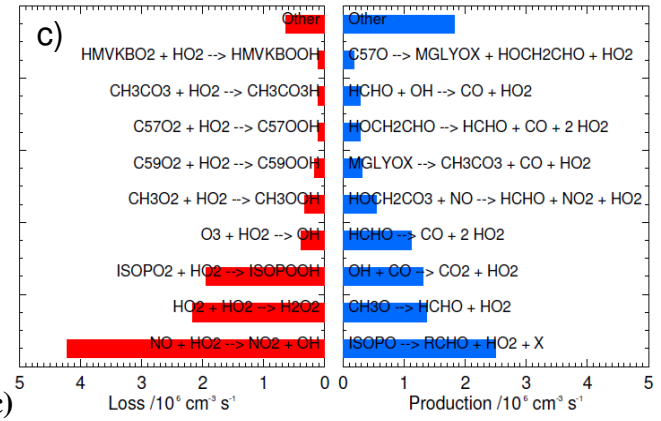

Fig. 7. Processes controlling the instantaneous production and loss of (a) $\mathrm{RO}_{\mathrm{x}}$ (b) $\mathrm{HO}_{\mathrm{x}}$ and (c) $\mathrm{HO}_{2}$ for a typical data point in the forest boundary layer (shown in red in Fig. 4). Species names are as given in the MCM.

We therefore conclude that at the $\mathrm{NO}_{\mathrm{x}}$ and isoprene concentrations experienced in this location during AMMA, isoprene has little overall impact on $\mathrm{HO}_{2}$ as the $\mathrm{NO}_{\mathrm{x}}$ concentrations are high enough to minimise peroxide formation and to increase the production of $\mathrm{HO}_{2}$ source species such as HCHO and other aldehydes. Thus isoprene cycling provides a "null" cycle for $\mathrm{HO}_{2}$ at these isoprene and $\mathrm{NO}_{\mathrm{x}}$ concentrations. We now investigate the chemical range for which this "null" cycle is valid.

\subsection{Sensitivity of $\mathrm{HO}_{2}$ to changes in isoprene at different isoprene and NO concentrations}

Figure 9 shows the results of a sensitivity study, using the single point described above, to investigate the combined effects of isoprene and $\mathrm{NO}_{\mathrm{x}}$ on the modelled $\mathrm{HO}_{2}$ in which the isoprene and $\mathrm{NO}_{\mathrm{x}}$ inputs to the model have been varied while maintaining all other species at their observed levels 


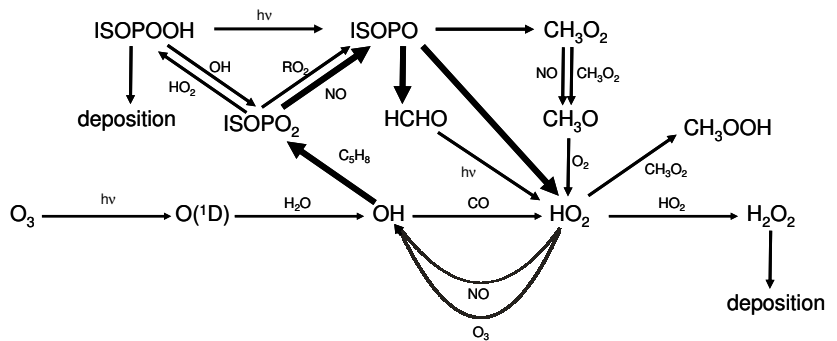

Fig. 8. Simplified schematic showing processes controlling radical budgets during AMMA. Bold lines indicate the dominant reactions in isoprene oxidation chemistry during AMMA.

(Table 3). The plot shows the ratio of the modelled $\mathrm{HO}_{2}$ for a base run in which isoprene and $\mathrm{NO}_{\mathrm{x}}$ were varied, compared to an analogous model run in which the isoprene concentrations were multiplied by a factor of ten, thus showing the effects of increasing isoprene concentration under different isoprene and $\mathrm{NO}_{\mathrm{x}}$ regimes. We split the chemical space into four regimes dependent on the $\mathrm{NO}_{\mathrm{x}}$ concentration, and discuss each in turn below.

Impact of isoprene at $50 \mathrm{ppt}>\mathrm{NO}>10 \mathrm{ppt}$

Figure 9 allows identification of a number of regimes affecting the modelled $\mathrm{HO}_{2}$. At low $\mathrm{NO}_{\mathrm{x}}$ levels $(\mathrm{NO}<50 \mathrm{ppt}$ ), loss of $\mathrm{HO}_{2}$ is dominated by $\mathrm{HO}_{2}+\mathrm{HO}_{2}$ and $\mathrm{HO}_{2}+\mathrm{RO}_{2}$, particularly $\mathrm{ISOPO}_{2}$, and $\mathrm{HO}_{2}$ is sensitive to changes in isoprene concentration. Increasing the isoprene concentration at such low $\mathrm{NO}_{\mathrm{x}}$ levels leads to decreased modelled $\mathrm{HO}_{2}$.

Impact of isoprene at $500 \mathrm{ppt}>\mathrm{NO}>50 \mathrm{ppt}$

As the $\mathrm{NO}_{\mathrm{x}}$ level increases, loss of $\mathrm{HO}_{2}$ becomes dominated by $\mathrm{HO}_{2}+\mathrm{NO}$ and the modelled $\mathrm{HO}_{2}$ becomes insensitive to isoprene. Although there is some peroxide formation at higher $\mathrm{NO}_{\mathrm{x}}$ concentrations, leading to loss of $\mathrm{HO}_{\mathrm{x}}$, the $\mathrm{HO}_{\mathrm{x}}$ loss is offset by direct $\mathrm{HO}_{2}$ production from $\mathrm{RO}$, formed by $\mathrm{RO}_{2}+\mathrm{NO}$, and $\mathrm{RO}$-generated $\mathrm{HCHO}$ which photolyses to produce $2 \mathrm{HO}_{2}$ radicals.

Impact of isoprene at $\mathrm{NO}>500 \mathrm{ppt}$

However, as the $\mathrm{NO}_{\mathrm{x}}$ level is increased further $(\mathrm{NO}>500 \mathrm{ppt})$ the modelled $\mathrm{HO}_{2}$ becomes sensitive to the isoprene input once more as the relative importance of $\mathrm{HO}_{2}$ production from alkoxy radicals such as $\mathrm{CH}_{3} \mathrm{O}$ and ISOPO increases due to increased production of these species from $\mathrm{RO}_{2}+\mathrm{NO}$ reactions, and the modelled $\mathrm{HO}_{2}$ increases if isoprene is raised at high $\mathrm{NO}_{\mathrm{x}}$ levels. Production of $\mathrm{HO}_{2}$ from alkoxy radicals also results in co-production of $\mathrm{HCHO}$, which increases the modelled $\mathrm{HO}_{2}$ further.

\section{Impact of isoprene at $\mathrm{NO}<10 \mathrm{ppt}$}

At low $\mathrm{NO}_{\mathrm{x}}$ and low isoprene levels $(<10 \mathrm{ppt}), \mathrm{HO}_{2}$ production and loss is dominated by $\mathrm{OH}+\mathrm{CO}$ and $\mathrm{HO}_{2}+\mathrm{HO}_{2}$ and $\mathrm{HO}_{2}+\mathrm{CH}_{3} \mathrm{O}_{2}$, and the modelled $\mathrm{HO}_{2}$ is relatively unaffected by isoprene. As the isoprene concentration increases, $\mathrm{HO}_{2}$ loss becomes dominated by reaction with $\mathrm{ISOPO}_{2}$ radicals, and the modelled $\mathrm{HO}_{2}$ is reduced on increasing isoprene. At higher isoprene concentrations and low $\mathrm{NO}_{\mathrm{x}}$, however, production of $\mathrm{HCHO}$ from $\mathrm{C}_{5} \mathrm{H}_{8}+\mathrm{O}_{3}$ reactions be-

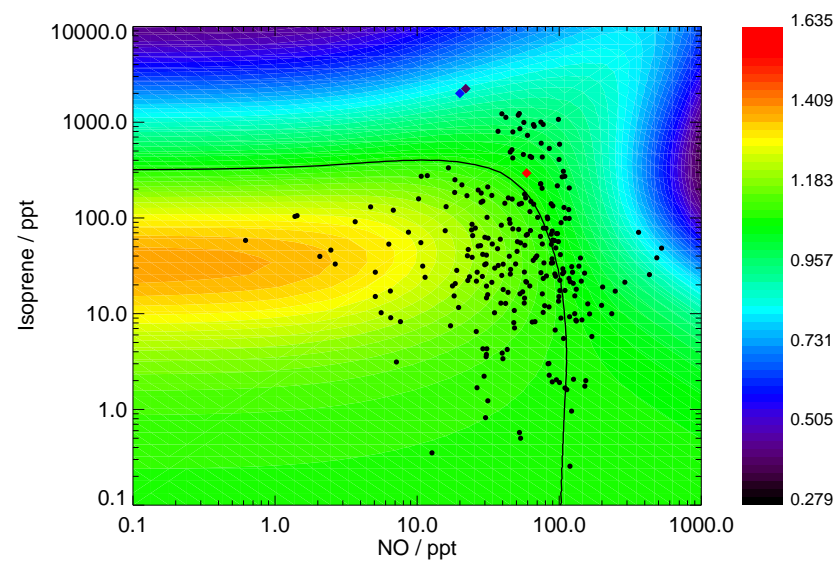

Fig. 9. Contour plot showing the fractional changes in modelled $\mathrm{HO}_{2}$ at different $\mathrm{NO}$ and isoprene concentrations relative to a model run where the isoprene concentration was a factor of ten lower (the y-axis refers to the lower isoprene concentrations). Model runs described here were unconstrained to $\mathrm{HCHO}$ and isoprene degradation products. The $1: 1$ ratio for the modelled $\mathrm{HO}_{2}$ concentrations is shown by the black line. Black circles indicate $\mathrm{NO}$ and isoprene concentrations encountered during AMMA, with the average conditions for AMMA shown by the red diamond. The blue diamond indicates the average NO and isoprene concentrations encountered during GABRIEL (Lelieveld et al., 2008) and the purple diamond the median isoprene and NO concentrations encountered during INTEX-A when isoprene was above $2 \mathrm{ppb}$ (http://www-air.larc.nasa.gov/missions/intexna/intexna.htm).

comes important, and the modelled $\mathrm{HO}_{2}$ is actually increased on increasing the isoprene input due to increased production from $\mathrm{HCHO}$ photolysis. At such high isoprene concentrations the modelled $\mathrm{HO}_{2}$ is relatively insensitive to the $\mathrm{NO}_{\mathrm{x}}$ input.

Overall, within the MCM concentrations of $\mathrm{HO}_{2}$ in the atmosphere are a complex function of the isoprene and $\mathrm{NO}$ concentrations, and efficient production of $\mathrm{HO}_{\mathrm{x}}$ species through isoprene and isoprene derived peroxy and alkoxy radicals can be achieved through formation of $\mathrm{HO}_{2}$ and $\mathrm{HCHO}$, with subsequent photolysis, from ISOPO radicals generated by reaction of $\mathrm{ISOPO}_{2}$ with NO.

\subsection{Influence of isoprene and $\mathrm{NO}_{x}$ on $\mathrm{HO}_{2}$ during AMMA}

During AMMA the mean isoprene concentration observed in the forest boundary layer was $(294 \pm 333) \mathrm{ppt}$, with a maximum of $1232 \mathrm{ppt}$, while the mean NO concentration was $(59 \pm 30)$ ppt. These concentrations are marked on Fig. 9, and compare to $(2000 \pm 760)$ ppt isoprene and $(20 \pm 20) \mathrm{ppt}$ NO for the GABRIEL campaign (Lelieveld et al., 2008), also marked on Fig. 9, although it should be noted that differences in ozone and $\mathrm{CO}$ concentrations between AMMA and GABRIEL and INTEX-A may contribute to the placement of the different campaigns in different chemical regimes. 
Data recorded during AMMA corresponds to a regime in which $\mathrm{HO}_{2}$ chemistry is relatively insensitive to variations in isoprene and is dominated by $\mathrm{NO}_{\mathrm{x}}$ due to efficient conversion of $\mathrm{ISOPO}_{2}$ back to $\mathrm{HO}_{2}$. This contrasts to the GABRIEL situation where $\mathrm{NO}$ concentrations are significantly lower and isoprene concentrations are significantly higher. At the lower $\mathrm{NO}_{\mathbf{x}}$ and higher isoprene concentrations observed during GABRIEL the modelled $\mathrm{HO}_{\mathbf{x}}$ will be more sensitive to changes in isoprene than for AMMA. Many of the suggested explanations for the problems simulating $\mathrm{HO}_{\mathrm{x}}$ rely upon the fate of the isoprenyl peroxy radicals when they do not react with NO (Lelieveld et al., 2008; Hofzumahaus et al., 2009; Paulot et al., 2009; Peeters et al., 2009; Da Silva et al., 2010). Under the AMMA conditions, mis-representation of this chemistry should not lead to significant failures to simulate $\mathrm{HO}_{\mathrm{x}}$ and given our observations of $\mathrm{HO}_{2}$ this seems to be the case.

\section{Sources and sinks of $\mathrm{HO}_{2}$ and $\mathrm{HO}_{x}$}

Although forest-impacted boundary layer air formed an important aspect of AMMA the aircraft campaign investigated air with very different characteristics, from the forest to the Sahel and from the surface to the mid-troposphere. We now examine the chemistry controlling $\mathrm{HO}_{\mathrm{x}}$ concentrations in these different geographical regions. We split the atmosphere into regions above rainforest $\left(7.3^{\circ} \mathrm{N}\right.$ to $\left.13.2^{\circ} \mathrm{N}\right)$ and Sahel $\left(>13.75^{\circ} \mathrm{N}\right)$ and examine the chemistry responsible for determining $\mathrm{HO}_{\mathrm{x}}$ and $\mathrm{HO}_{2}$ concentrations in each region.

Figures 7 and 10 show the $\mathrm{RO}_{\mathrm{x}}, \mathrm{HO}_{\mathrm{x}}$ and $\mathrm{HO}_{2}$ budgets for typical data points representative of the forest and Sahel boundary layers, respectively. The data points are shown in Fig. 4. The data point over the forest is that described previously in Sect. 5, and refers to a data point taken at 13:53 GMT on day 229 in the forest boundary layer (latitude $10.13^{\circ} \mathrm{N}$, longitude $2.69^{\circ} \mathrm{E}$, pressure $951.5 \mathrm{hPa}$ ). The data point over the Sahel was taken at 14:01 GMT on day 223 in the Sahel boundary layer (latitude $14.48^{\circ} \mathrm{N}$, longitude $4.35^{\circ} \mathrm{E}$, pressure $961.3 \mathrm{hPa}$ ). Concentrations of measured species for these two points are listed in Table 3.

The main source of $\mathrm{HO}_{\mathrm{x}}$ in both forest and Sahel boundary layers is ozone photolysis followed by the reaction of $\mathrm{O}\left({ }^{1} \mathrm{D}\right)+\mathrm{H}_{2} \mathrm{O}$. This accounts for over $42 \%$ of the total $\mathrm{HO}_{\mathrm{x}}$ production over the forest and $61 \%$ over the Sahel. In both regions this is followed by reaction of $\mathrm{CH}_{3} \mathrm{O}$, produced mainly by $\mathrm{CH}_{3} \mathrm{O}_{2}+\mathrm{NO}$, with $\mathrm{O}_{2}$. Over the Sahel, these two processes account for approximately $90 \%$ of the total $\mathrm{HO}_{\mathrm{x}}$ production, with the remaining $10 \%$ predominantly from photolysis of $\mathrm{HCHO}$ and $\mathrm{H}_{2} \mathrm{O}_{2}$. Over the forest region, $\mathrm{O}_{3}$ photolysis and $\mathrm{CH}_{3} \mathrm{O}+\mathrm{O}_{2}$ account for only approximately $50 \%$ of the total $\mathrm{HO}_{\mathrm{x}}$ production, with contributions from numerous species, but with notable contributions from ISOPO radicals and photolysis of $\mathrm{HCHO}$.
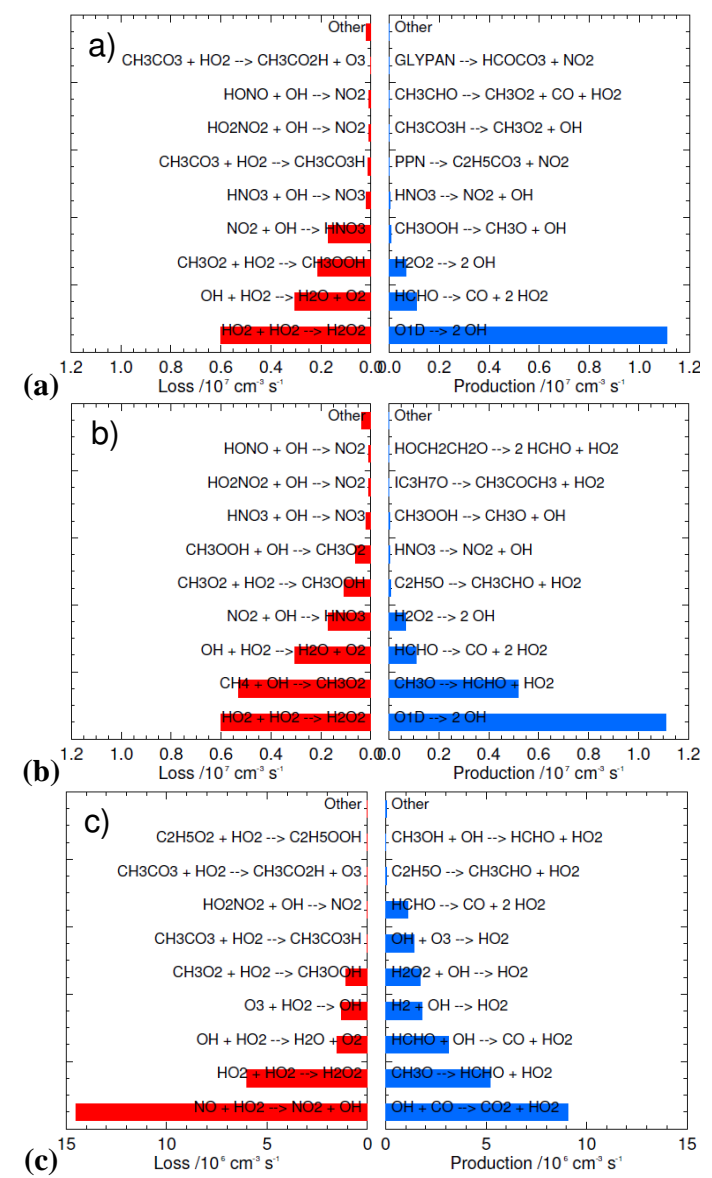

Fig. 10. Processes controlling the instantaneous production and loss of (a) $\mathrm{RO}_{\mathrm{x}}$ (b) $\mathrm{HO}_{\mathrm{x}}$ and (c) $\mathrm{HO}_{2}$ for a typical data point in the Sahel boundary layer (shown in blue in Fig. 4). Species names are as given in the MCM.

Loss processes for $\mathrm{HO}_{\mathrm{x}}$ over the forest are dominated by $\mathrm{C}_{5} \mathrm{H}_{8}+\mathrm{OH}$, producing ISOPO 2 radicals, with a large number of reactions involving VOCs and their oxidation products contributing to the total $\mathrm{HO}_{\mathrm{x}}$ loss. In contrast, loss processes over the Sahel are dominated by the $\mathrm{HO}_{2}$ selfreaction, $\mathrm{CH}_{4}+\mathrm{OH}$ and $\mathrm{OH}+\mathrm{HO}_{2}$ with considerably fewer contributions from other reactions. Losses due to aerosol were minimal, representing less than $1.5 \%$ of the total loss for $\mathrm{HO}_{2}$ and less for $\mathrm{OH}$.

Figures $7 \mathrm{c}$ and 10c show the modelled $\mathrm{HO}_{2}$ budgets for the typical forest and Sahel points. Over the Sahel, the most significant reactions for $\mathrm{HO}_{2}$ production are $\mathrm{OH}+\mathrm{CO}$ and $\mathrm{CH}_{3} \mathrm{O}+\mathrm{O}_{2}$. Over the forest, however, total production of $\mathrm{HO}_{2}$ from all four ISOPO radical isomers combined is of greater importance than either $\mathrm{OH}+\mathrm{CO}$ or $\mathrm{CH}_{3} \mathrm{O}+\mathrm{O}_{2}$ alone, and $\mathrm{HO}_{2}$ production from ISOPBO alone is of equal importance as $\mathrm{OH}+\mathrm{CO}$ or $\mathrm{CH}_{3} \mathrm{O}+\mathrm{O}_{2}$. In addition, production of $\mathrm{HO}_{2}$ from $\mathrm{HCHO}$ photolysis is twice as important over the forest than over the Sahel. 
Loss of $\mathrm{HO}_{2}$ is dominated by $\mathrm{NO}+\mathrm{HO}_{2}$ and $\mathrm{HO}_{2}+\mathrm{HO}_{2}$ in both regions, but while these reactions account for approximately $85 \%$ of the total $\mathrm{HO}_{2}$ over the Sahel they account for only $62 \%$ over the forest. The high biogenic emissions over the forest lead to a greater dominance of $\mathrm{HO}_{2}$ loss through reaction with $\mathrm{RO}_{2}$, particularly those derived from isoprene.

In general, reactions of $\mathrm{HO}_{2}$ with $\mathrm{RO}_{2}$, resulting in peroxide formation, are of greater importance over the forest than the Sahel, indicating the difference in VOC emissions between the two regions.

\section{Model sensitivity}

All models make various assumptions and approximations. The impact of some of these on the conclusions described earlier (Sects. 4 and 5) are analysed here.

\subsection{Influence of photolysis rates}

Instrumental problems with the $j\left(\mathrm{O}^{1} \mathrm{D}\right)$ downward facing radiometer led to the total $j\left(\mathrm{O}^{1} \mathrm{D}\right)$ being estimated from measurements of the upward pointing $j\left(\mathrm{O}^{1} \mathrm{D}\right)$ and the total $j\left(\mathrm{NO}_{2}\right)$ for several flights during the campaign, and may result in some uncertainty in the photolysis input to the model. Assumptions made in the calibration procedure to account for the non-linearity of the $j\left(\mathrm{O}^{1} \mathrm{D}\right)$ calibration factors for total ozone column, temperature and solar zenith angle, may have also introduced some systematic error to the $j\left(\mathrm{O}^{1} \mathrm{D}\right)$, requiring a potential reduction in the $j\left(\mathrm{O}^{1} \mathrm{D}\right)$ used in the base model run by $30 \%$ (Brookes, 2009).

A reduction in $j\left(\mathrm{O}^{1} \mathrm{D}\right)$ by $30 \%$ changes the gradient of modelled to observed $\mathrm{HO}_{2}$ from $(1.23 \pm 0.11)$ to $(1.05 \pm 0.09)$. This may provide some explanation for the slight overestimation of $\mathrm{HO}_{2}$ in the model and illustrates the need for stringent and well characterised calibration procedures for constraints in the model.

\subsection{Influence of monoterpenes}

Monoterpene emissions are a significant source of carbon to the atmosphere (Adams et al., 2001). During AMMA monoterpene concentrations were measured on several flights (Capes et al., 2009), but measurements were sporadic and with relatively low time resolution. Average concentrations of $\alpha$-pinene, $\beta$-pinene, camphene and limonene were included in the model as the mean concentration for the flight for every time point on each flight on which they were measured, with a maximum total monoterpene concentration of $130 \mathrm{ppt}$. The monoterpenes were treated as $\alpha$-pinene (i.e. $[\alpha$-pinene $]=[\alpha$-pinene $]+[\beta$ pinene $]+[$ camphene $]+[$ limonene $])$ due to the availability of a full $\alpha$-pinene degradation scheme in the MCM. However, little difference on the model results was observed with the gradient of the modelled to observed $\mathrm{HO}_{2}$ changing from $(1.23 \pm 0.11)$ to $(1.18 \pm 0.10)$. Thus we conclude that not having monoterpene observations does not significantly impact the simulations performed here or the conclusions reached.

\subsection{Impact of deposition timescale}

Removal of all species is included in the model to represent physical loss of species through deposition. The default unimolecular rate coefficient used to describe this deposition process in the model is $1 \times 10^{-5} \mathrm{~s}^{-1}$, corresponding to a lifetime approximately of $24 \mathrm{~h}$. During the sensitivity analysis the rate coefficient was varied between $2.78 \times 10^{-4}$ and $2.31 \times 10^{-6} \mathrm{~s}^{-1}$, corresponding to lifetimes between $1 \mathrm{~h}$ and 5 days. Modelled $\mathrm{HO}_{2}$ was not significantly affected by the changes to the deposition rate, with the gradient of the modelled to observed $\mathrm{HO}_{2}$ changing from $(1.10 \pm 0.10)$ for a lifetime of $1 \mathrm{~h}$ to $(1.23 \pm 0.11)$ for a lifetime of approximately $24 \mathrm{~h}$ to $(1.25 \pm 0.11)$ for a lifetime of 5 days. Thus we conclude that our model simulations are not significantly influenced by this choice as most of the $\mathrm{HO}_{\mathrm{x}}$ sources and sinks in the model are observed, or are short lived and thus unaffected by deposition.

\section{Conclusions}

Aircraft measurements of $\mathrm{OH}$ and $\mathrm{HO}_{2}$ made during the AMMA campaign in 2006 have been compared to model calculations using the Dynamically Simple Model of Atmospheric Chemical Complexity (DSMACC). The model makes a systematic overestimation of $\mathrm{OH}$, most likely reflecting instrumental issues with $\mathrm{OH}$ detection during the campaign, and this work has focussed on understanding the $\mathrm{HO}_{2}$ concentrations. Modelled $\mathrm{HO}_{2}$ concentrations were found to agree with observations within the calibration uncertainties of the $\mathrm{HO}_{2}$ measurement and uncertainties associated with the photolysis rate input to the model.

$\mathrm{HO}_{\mathrm{x}}$ budget analyses indicate that $\mathrm{HO}_{\mathrm{x}}$ concentrations in West Africa are controlled by relatively simple photochemistry, with $\mathrm{HO}_{\mathrm{x}}$ production generally dominated by ozone production followed by reaction of $\mathrm{O}\left({ }^{1} \mathrm{D}\right)$ with water, while $\mathrm{HO}_{\mathrm{x}}$ removal processes are dominated by $\mathrm{HO}_{2}+\mathrm{HO}_{2}$ and $\mathrm{HO}_{2}+\mathrm{RO}_{2}$. Isoprene chemistry was found to influence the $\mathrm{HO}_{\mathrm{x}}$ budget over forested regions.

Despite recent evidence indicating misrepresentation of $\mathrm{HO}_{\mathrm{x}}$ chemistry in high isoprene and low $\mathrm{NO}_{\mathrm{x}}$ environments we observed no dependence of model success on isoprene concentration, and conclude that under the conditions encountered during the AMMA campaign $\mathrm{NO}_{\mathrm{x}}$ levels were sufficiently high to enable efficient recycling of $\mathrm{HO}_{\mathrm{x}}$ species through $\mathrm{RO}_{2}+\mathrm{NO}$ reactions. 
Acknowledgements. Based on a French initiative, AMMA was built by an international scientific group and is currently funded by a large number of agencies, especially from France, the UK, the US and Africa. This work was funded by the EU and by the UK Natural Environment Research Council through the AMMA-UK Consortium grant and the National Centre for Atmospheric Science.

\section{References}

Adams, J. M., Constable, J. V. H., Guenther, A. B., and Zimmerman, P.: An estimate of natural volatile organic compound emissions from vegetation since the last glacial maximum, Chemosphere Glob. Change. Sci., 2, 73-91, 2001.

Anderson, T. L. and Ogren, J. A.: Determining aerosol radiative properties using the TSI 3563 integrating nephelometer, Aerosol Sci. Technol., 29, 57-69, 1998.

Atkinson, R., Baulch, D. L., Cox, R. A., Crowley, J. N., Hampson, R. F., Hynes, R. G., Jenkin, M. E., Rossi, M. J., and Troe, J.: Evaluated kinetic and photochemical data for atmospheric chemistry: Volume $\mathrm{I}-$ gas phase reactions of $\mathrm{O}_{\mathrm{x}}, \mathrm{HO}_{\mathrm{x}}, \mathrm{NO}_{\mathrm{x}}$ and $\mathrm{SO}_{\mathrm{x}}$ species, Atmos. Chem. Phys., 4, 1461-1738, doi:10.5194/acp-41461-2004, 2004.

Bloss, W., Evans, M., Lee, J., Sommariva, R., Heard, D., and Pilling, M.: The oxidative capacity of the troposphere: Coupling of field measurements of $\mathrm{OH}$ and a global chemistry transport model, Faraday Discuss., 130, 425-436, 2005.

Bohn, B., Corlett, G. K., Gillmann, M., Sanghavi, S., Stange, G., Tensing, E., Vrekoussis, M., Bloss, W. J., Clapp, L. J., Kortner, M., Dorn, H.-P., Monks, P. S., Platt, U., Plass-Dülmer, C., Mihalopoulos, N., Heard, D. E., Clemitshaw, K. C., Meixner, F. X., Prevot, A. S. H., and Schmitt, R.: Photolysis frequency measurement techniques: results of a comparison within the ACCENT project, Atmos. Chem. Phys., 8, 5373-5391, doi:10.5194/acp-85373-2008, 2008.

Brookes, D.: Characterisation of a PERCA instrument and measurements of peroxy radicals during the West African Monsoon 2006, PhD thesis, University of Leicester, UK, 2009.

Brough, N., Reeves, C. E., Penkett, S. A., Stewart, D. J., Dewey, K., Kent, J., Barjat, H., Monks, P. S., Ziereis, H., Stock, P., Huntrieser, H., and Schlager, H.: Intercomparison of aircraft instruments on board the C-130 and Falcon 20 over southern Germany during EXPORT 2000, Atmos. Chem. Phys., 3, 21272138, doi:10.5194/acp-3-2127-2003, 2003.

Butler, T. M., Taraborrelli, D., Brühl, C., Fischer, H., Harder, H., Martinez, M., Williams, J., Lawrence, M. G., and Lelieveld, J.: Improved simulation of isoprene oxidation chemistry with the ECHAM5/MESSy chemistry-climate model: lessons from the GABRIEL airborne field campaign, Atmos. Chem. Phys., 8, 4529-4546, doi:10.5194/acp-8-4529-2008, 2008.

Capes, G., Murphy, J. G., Reeves, C. E., McQuaid, J. B., Hamilton, J. F., Hopkins, J. R., Crosier, J., Williams, P. I., and Coe, H.: Secondary organic aerosol from biogenic VOCs over West Africa during AMMA, Atmos. Chem. Phys., 9, 3841-3850, doi:10.5194/acp-9-3841-2009, 2009.

Cardenas, L. M., Brassington, D. J., Allan, B. J., Coe, H., Alicke, B., Platt, U., Wilson, K. M., Plane, J. M. C., and Penkett, S. A.: Intercomparison of formaldehyde measurements in clean and polluted atmospheres, J. Atmos. Chem., 37, 53-80, 2000.
Commane, R., Floquet, C. F. A., Ingham, T., Stone, D., Evans, M. J., and Heard, D. E.: Observations of $\mathrm{OH}$ and $\mathrm{HO}_{2}$ radicals over West Africa, Atmos. Chem. Phys., 10, 8783-8801, doi:10.5194/acp-10-8783-2010, 2010.

Da Silva, G., Graham, C., and Wang, Z. F.: Unimolecular $\beta$ hydroperoxy radical decomposition with $\mathrm{OH}$ recycling in the photochemical oxidation of isoprene, Environ. Sci. Technol., 44, 250-256, 2010.

Dillon, T. J. and Crowley, J. N.: Direct detection of OH formation in the reactions of $\mathrm{HO}_{2}$ with $\mathrm{CH}_{3} \mathrm{C}(\mathrm{O}) \mathrm{O}_{2}$ and other substituted peroxy radicals, Atmos. Chem. Phys., 8, 4877-4889, doi:10.5194/acp-8-4877-2008, 2008.

Edwards, G. D. and Monks, P. S.: Performance of a singlemonochromator diode array spectroradiometer for the determination of actinic flux and atmospheric photolysis frequencies, J. Geophys. Res., 108(D16), 8546, doi:10.1029/2002JD002844, 2003.

Ehhalt, D. H. and Rohrer, F.: The tropospheric cycle of $\mathrm{H}_{2}$ : a critical review, Tellus B, 61, 500-535, 2009.

Emmerson, K. M. and Evans, M. J.: Comparison of tropospheric gas-phase chemistry schemes for use within global models, Atmos. Chem. Phys., 9, 1831-1845, doi:10.5194/acp-9-1831-2009, 2009.

Gerbig, C., Schmitgen, S., Kley, D., Volz-Thomas, A., Dewey, K., and Haaks, D.: An improved fast-response vacuum UV resonance fluorescence $\mathrm{CO}$ instrument, J. Geophys. Res.-Atmos., 104, 1699-1704, 1999.

Hasson, A. S., Tyndall, G. S., and Orlando, J. J.: A product yield study of the reaction of $\mathrm{HO}_{2}$ radicals with ethyl peroxy $\left(\mathrm{C}_{2} \mathrm{H}_{5} \mathrm{O}_{2}\right)$, acetyl peroxy $\left(\mathrm{CH}_{3} \mathrm{C}(\mathrm{O}) \mathrm{O}_{2}\right)$, and acetonyl peroxy $\left(\mathrm{CH}_{3} \mathrm{C}(\mathrm{O}) \mathrm{CH}_{2} \mathrm{O}_{2}\right)$ radicals, J. Phys. Chem. A, 108, 5979-5989, 2004.

Heard, D. E. and Pilling, M. J.: Measurement of $\mathrm{OH}$ and $\mathrm{HO}_{2}$ in the troposphere, Chem. Rev., 103, 5163-5198, 2003.

Hewitt, C. N., Lee, J. D., MacKenzie, A. R., Barkley, M. P., Carslaw, N., Carver, G. D., Chappell, N. A., Coe, H., Collier, C., Commane, R., Davies, F., Davison, B., DiCarlo, P., Di Marco, C. F., Dorsey, J. R., Edwards, P. M., Evans, M. J., Fowler, D., Furneaux, K. L., Gallagher, M., Guenther, A., Heard, D. E., Helfter, C., Hopkins, J., Ingham, T., Irwin, M., Jones, C., Karunaharan, A., Langford, B., Lewis, A. C., Lim, S. F., MacDonald, S. M., Mahajan, A. S., Malpass, S., McFiggans, G., Mills, G., Misztal, P., Moller, S., Monks, P. S., Nemitz, E., Nicolas-Perea, V., Oetjen, H., Oram, D. E., Palmer, P. I., Phillips, G. J., Pike, R., Plane, J. M. C., Pugh, T., Pyle, J. A., Reeves, C. E., Robinson, N. H., Stewart, D., Stone, D., Whalley, L. K., and Yin, X.: Overview: oxidant and particle photochemical processes above a south-east Asian tropical rainforest (the OP3 project): introduction, rationale, location characteristics and tools, Atmos. Chem. Phys., 10, 169-199, doi:10.5194/acp-10169-2010, 2010.

Hofzumahaus, A., Rohrer, F., Lu, K., Bohn, B., Brauers, T., Chang, C. C., Fuchs, H., Holland, F., Kita, K., Kondo, Y., Li, X., Lou, S., Shao, M., Zeng, L., Wahner, A., and Zhang, Y.: Amplified trace gas removal in the troposphere, Science, 324, 1702-1704, 2009.

Hopkins, J. R., Lewis, A. C., and Read, K. A.: A two-column method for long-term monitoring of non-methane hydrocarbons (NMHCs) and oxygenated volatile organic compounds (oVOCs), J. Environ. Monitor., 5, 8-13, 2003. 
Hopkins, J. R., Evans, M. J., Lee, J. D., Lewis, A. C., H Marsham, J., McQuaid, J. B., Parker, D. J., Stewart, D. J., Reeves, C. E., and Purvis, R. M.: Direct estimates of emissions from the megacity of Lagos, Atmos. Chem. Phys., 9, 8471-8477, doi:10.5194/acp9-8471-2009, 2009.

Jaegle, L., Jacob, D. J., Brune, W. H., Faloona, I., Tan, D., Heikes, B. G., Kondo, Y., Sachse, G. W., Anderson, B., Gregory, G. L., Singh, H. B., Pueschel, R., Ferry, G., Blake, D. R., and Shetter, R. E.: Photochemistry of $\mathrm{HO}_{\mathrm{x}}$ in the uppoer troposphere at northern midlatitudes, J. Geophys. Res., 105(D3), 3877-3892, 2000.

Jenkin, M. E., Saunders, S. M., Wagner, V., and Pilling, M. J.: Protocol for the development of the Master Chemical Mechanism, MCM v3 (Part B): tropospheric degradation of aromatic volatile organic compounds, Atmos. Chem. Phys., 3, 181-193, doi:10.5194/acp-3-181-2003, 2003.

Jenkin, M. E., Hurley, M. D., and Wallington, T. J.: Investigation of the radical product channel of the $\mathrm{CH}_{3} \mathrm{C}(\mathrm{O}) \mathrm{O}_{2}+\mathrm{HO}_{2}$ reaction in the gas phase, Phys. Chem. Chem. Phys., 9, 3149-3162, 2007.

Jenkin, M. E., Hurley, M. D., and Wallington, T. J.: Investigation of the radical product channel of the $\mathrm{CH}_{3} \mathrm{C}(\mathrm{O}) \mathrm{CH}_{2} \mathrm{O}_{2}+\mathrm{HO}_{2}$ reaction in the gas phase, Phys. Chem. Chem. Phys., 10, 42744280, 2008.

Kubistin, D., Harder, H., Martinez, M., Rudolf, M., Sander, R., Bozem, H., Eerdekens, G., Fischer, H., Gurk, C., Klüpfel, T., Königstedt, R., Parchatka, U., Schiller, C. L., Stickler, A., Taraborrelli, D., Williams, J., and Lelieveld, J.: Hydroxyl radicals in the tropical troposphere over the Suriname rainforest: comparison of measurements with the box model MECCA, Atmos. Chem. Phys. Discuss., 8, 15239-15289, doi:10.5194/acpd8-15239-2008, 2008.

Lawrence, M. G., Crutzen, P. J., Rasch, P. J., Eaton, B. E., and Mahowald, N. M.: Amodel for studies of tropospheric photochemistry: Description, global distributions, and evaluation, J. Geophys. Res., 104(D21), 26245-26277, 1999.

Lebel, T., Parker, D. J., Flamant, C., Bourles, B., Marticorena, B., Mougin, E., Peugeot, C., Diedhiou, A., Haywood, J. M., Ngamini, J. B., Polcher, J., Redelsperger, J. L., and Thorncroft, C. D.: The AMMA field campaigns: Multiscale and multidisciplinary observations in the West African region, Q. J. Roy. Meteor. Soc., 136(S1), 8-33, doi:10.1002/qj.486, 2009.

Le Crane, J. P., Rayez, M. T., Rayez, J. C., and Villenave, E.: Areinvestigation of the kinetics and the mechanism of the $\mathrm{CH}_{3} \mathrm{C}(\mathrm{O}) \mathrm{O}_{2}+\mathrm{HO}_{2}$ reaction using both experimental and theoretical approaches, Phys. Chem. Chem. Phys., 8, 2163-2171, 2006.

Lelieveld, J., Peters, W., Dentener, F. J., and Krol ,M. C.: Stability of tropospheric hydroxyl chemistry, J. Geophys. Res., 107(D23), 4715, doi:10.1029/2002JD002272, 2002.

Lelieveld, J., Butler, T. M., Crowley, J. N., Dillon, T. J., Fischer, H., Ganzeveld, L., Harder, H., Lawrence, M. G., Martinez, M., Taraborrelli, D., and Williams, J.: Atmospheric oxidation capacity sustained by atropical forest, Nature, 452, 737-740, 2008.

McNaughton, C. S., Clarke, A. D., Kapustin, V., Shinozuka, Y., Howell, S. G., Anderson, B. E., Winstead, E., Dibb, J., Scheuer, E., Cohen, R. C., Wooldridge, P., Perring, A., Huey, L. G., Kim, S., Jimenez, J. L., Dunlea, E. J., DeCarlo, P. F., Wennberg, P. O., Crounse, J. D., Weinheimer, A. J., and Flocke, F.: Observations of heterogeneous reactions between Asian pollution and mineral dust over the Eastern North Pacific during INTEX-B, Atmos. Chem. Phys., 9, 8283-8308, doi:10.5194/acp-9-8283-2009, 2009.

Mao, J., Ren, X., Brune, W. H., Olson, J. R., Crawford, J. H., Fried, A., Huey, L. G., Cohen, R. C., Heikes, B., Singh, H. B., Blake, D. R., Sachse, G. W., Diskin, G. S., Hall, S. R., and Shetter, R. E.: Airborne measurement of $\mathrm{OH}$ reactivity during INTEX-B, Atmos. Chem. Phys., 9, 163-173, doi:10.5194/acp-9-163-2009, 2009.

Mari, C. H, Reeves, C. E., Law, K. S., Ancellet, G., AndresHernandez, M. D., Barret, B., Bechara, J., Borbon, A., Bouarar, I., Cairo, F., Commane, R., Delon, C., Evans, M. J., Fierli, F., Floquet, C., Galy-Lacaux, C., Heard, D. E., Homan, C. D., Ingham, T., Larsen, N., Lewis, A. C., Liousse, C., Murphy, J. G., Orlandi, E., Oram, D. E., Saunois, M., Serca, D., Stewart, D. J., Stone, D., Thouret, V., van Velthoven, P., and Williams, J. E.: Atmospheric composition of West Africa : highlights from the AMMA international program, Atmos. Sci. Lett., doi:10.1002/asl.289, 2010.

Martinez, M., Harder, H., Kubistin, D., Rudolf, M., Bozem, H., Eerdekens, G., Fischer, H., Klüpfel, T., Gurk, C., Königstedt, R., Parchatka, U., Schiller, C. L., Stickler, A., Williams, J., and Lelieveld, J.: Hydroxyl radicals in the tropical troposphere over the Suriname rainforest: airborne measurements, Atmos. Chem. Phys., 10, 3759-3773, doi:10.5194/acp-10-3759-2010, 2010.

Monks, P. S.: Gas-phase radical chemistry in the troposphere, Chem. Soc. Rev., 34(5), 376-395, 2005.

Murphy, J. G., Oram, D. E., and Reeves, C. E.: Measurements of volatile organic compounds over West Africa, Atmos. Chem. Phys., 10, 5281-5294, doi:10.5194/acp-10-5281-2010, 2010.

Novelli, P. C., Lang, P. M., Masarie, K. A., Hurst, D. F., Myers, R., and Elkins, J. W.: Molecular hydrogen in the troposphere: Global distribution and budget, J. Geophys. Res., D23, 3042730444, 1999.

Olson, J. R., Crawford, J. H., Davis, D. D., Chen, G., Avery, M., Barrick, J. D. W., Sachse, G. W., Vay, S. A., Sandholm, S. T., Tan, D., Brune, W. H., Faloona, I. C., Heikes, B. G., Shetter, R. E., Lefer, B. L., Singh, H. B., Talbot, R. W., and Blake, D. R.: Seasonal differences in the photochemistry of the South Pacific: Acomparison of observations and model results from PEMTropics A and B, J. Geophys. Res., 106, 32749-32766, 2001.

Olson, J. R., Crawford, J. H., Chen, G., Fried, A., Evans, M. J., Jordan, C. E., Sandholm, S. T., Davis, D. D., Anderson, B. E., Avery, M. A., Barrick, J. D., Blake, D. R., Brune, W. H., Eisele, F. L., Flocke, F., Harder, H, Jacob, D. J., Kondo, Y., Lefer, B. L., Martinez, M., Mauldin, R. L., Sachse, G. W., Shetter, R. E., Singh, H. N., Talbot, R. W., and Tan, D.: Testing fast photochemical theory during TRACE-P based on measurements of $\mathrm{OH}, \mathrm{HO}_{2}$ and $\mathrm{CH}_{2} \mathrm{O}$, J. Geophys. Res., 109, D15S10, doi:10.1029/2003JD004278, 2004.

Olson, J. R., Crawford, J. H., Chen, G., Brune, W. H., Faloona, I. C., Tan, D., Harder, H., and Martinez, M.: Areevaluation of airborne $\mathrm{HO}_{\mathrm{x}}$ observations from NASA field campaigns, J. Geophys. Res., 111, D10301, doi:10.1029/2005JD006617, 2006.

Paulot, F., Crounse, J. D., Kjaergaard, H. G., Kurten, A., St. Clair, J. M., Seinfeld, J. H., and Wennberg, P. O.: Unexpected epoxide formation in the gas-phase photooxidation of isoprene, Science, 325, 730-733, 2009.

Peeters, J., Nguyen, T. L., and Vereecken, L.: $\mathrm{HO}_{\mathrm{x}}$ radical regener- 
ation in the oxidation of isoprene, Phys. Chem. Chem. Phys., 11, 28, 5935-5939, 2009.

Pugh, T. A. M., MacKenzie, A. R., Hewitt, C. N., Langford, B., Edwards, P. M., Furneaux, K. L., Heard, D. E., Hopkins, J. R., Jones, C. E., Karunaharan, A., Lee, J., Mills, G., Misztal, P., Moller, S., Monks, P. S., and Whalley, L. K.: Simulating atmospheric composition over a South-East Asian tropical rainforest: performance of a chemistry box model, Atmos. Chem. Phys., 10, 279-298, doi:10.5194/acp-10-279-2010, 2010.

Ravishankara, A. R.: Heterogeneous and multiphase chemistry in the troposphere, Science, 276, 1058-1065, 1997.

Redelsperger, J. L., Thorncroft, C. D., Diedhiou, A., Lebel, T., Parker, D. J., and Polcher, J.: African monsoon multidisciplinary analysis: an international research project and field campaign, B. Am. Meteorol. Soc., 87, 1739-1746, 2006.

Reeves, C. E., Formenti, P., Afif, C., Ancellet, G., Attié, J.-L., Bechara, J., Borbon, A., Cairo, F., Coe, H., Crumeyrolle, S., Fierli, F., Flamant, C., Gomes, L., Hamburger, T., Jambert, C., Law, K. S., Mari, C., Jones, R. L., Matsuki, A., Mead, M. I., Methven, J., Mills, G. P., Minikin, A., Murphy, J. G., Nielsen, J. K., Oram, D. E., Parker, D. J., Richter, A., Schlager, H., Schwarzenboeck, A., and Thouret, V.: Chemical and aerosol characterisation of the troposphere over West Africa during the monsoon period as part of AMMA, Atmos. Chem. Phys., 10, 7575-7601, doi:10.5194/acp-10-7575-2010, 2010.

Ren, R., Olson, J. R., Crawford, J. H., Brune, W. H., Mao, J., Long, R. B., Chen, Z., Chen, G., Avery, M. A., Sachse, G. W., Barrick, J. D., Diskin, G. S., Huey, L. G., Fried, A., Cohen, R. C., Heikes, B., Wennberg, P. O., Singh, H. B., Blake, D. R., and Shetter, R. E.: $\mathrm{HO}_{\mathrm{x}}$ chemistry during INTEX-A2004: Observation, model calculation, and comparison with previous studies, J. Geophys. Res., 113, D05310, doi:10.1029/2007JD009166, 2008.

Sander, S. P, Friedl, R. R., Golden, D. M., Kurylo, M. J., Moortgat, G. K., Keller-Rudek, H., Wine, P., Ravishankara, A. R., Kolb, C. E., Molina, M. J., Finlayson-Pitts, B. J., Huie, R. E., and Orkin, V. L.: Chemical kinetics and photochemical data for use in atmospheric studies, evaluation number 15, JPL Publication 06-02, 2006.

Sandu, A. and Sander, R.: Technical note: Simulating chemical systems in Fortran90 and Matlab with the Kinetic PreProcessor KPP-2.1, Atmos. Chem. Phys., 6, 187-195, doi:10.5194/acp-6187-2006, 2006.

Saunders, S. M., Jenkin, M. E., Derwent, R. G., and Pilling, M. J.: Protocol for the development of the Master Chemical Mechanism, MCM v3 (Part A): tropospheric degradation of nonaromatic volatile organic compounds, Atmos. Chem. Phys., 3, 161-180, doi:10.5194/acp-3-161-2003, 2003.

Saxton, J. E., Lewis, A. C., Kettlewell, J. H., Ozel, M. Z., Gogus, F., Boni, Y., Korogone, S. O. U., and Sera, D.: Isoprene and monoterpene measurements in a secondary forest in northern Benin, Atmos. Chem. Phys., 7, 4095-4106, doi:10.5194/acp-74095-2007, 2007.
SCIAMACHY Satellite Data, available at: http://www.iup. uni-bremen.de/sciamachy/NIR_NADIR_WFM_DOAS/ last access: January, 2010.

Smith, S. C., Lee, J. D., Bloss, W. J., Johnson, G. P., Ingham, T., and Heard, D. E.: Concentrations of $\mathrm{OH}$ and $\mathrm{HO}_{2}$ radicals during NAMBLEX: measurements and steady state analysis, Atmos. Chem. Phys., 6, 1435-1453, doi:10.5194/acp-6-1435-2006, 2006.

Singh, H. B., Brune, W. H., Crawford, J. H., Flocke, F., and Jacob, D. J.: Chemistry and transport of pollution over the Gulf of Mexico and the Pacific: spring 2006 INTEX-B campaign overview and first results, Atmos. Chem. Phys., 9, 2301-2318, doi:10.5194/acp-9-2301-2009, 2009.

Stewart, D. J., Taylor, C. M., Reeves, C. E., and McQuaid, J. B.: Biogenic nitrogen oxide emissions from soils: impact on $\mathrm{NO}_{\mathrm{x}}$ and ozone over west Africa during AMMA (African Monsoon Multidisciplinary Analysis): observational study, Atmos. Chem. Phys., 8, 2285-2297, doi:10.5194/acp-8-2285-2008, 2008.

Tan, D., Faloona, I., Simpas, J. B., Brune, W., Olson, J., Crawford, J., Avery, M., Sachse, G., Vay, S., Sandholm, S., Guan, H. W., Vaughn, T., Mastromarino, J., Heikes, B., Snow, J., Podolske, J., and Singh, $\mathrm{H}$.: $\mathrm{OH}$ and $\mathrm{HO}_{2}$ in the tropical Pacific: Results from PEM-Tropics B, J. Geophys. Res., 106, 32667-32681, 2001.

Thornton, J. A., Jaegle, L., and McNeill, V. F.: Assessing known pathways for $\mathrm{HO}_{2}$ in aqueous atmospheric aerosols: regional and global impacts on tropospheric oxidants, J. Geophys. Res., 113, D05303, doi:10.1029/2007JD009236, 2008.

Total Ozone Mapping Spectrometer (TOMS) Satellite Data, available at: http://toms.gsfc.nasa.gov/ozone/ozone_v8.html last access: January, 2010.

Wang, Y., Jacob, D. J., and Logan, J. A.: Global simulation of tropospheric $\mathrm{O}_{3}-\mathrm{NO}_{\mathrm{X}}$-hydrocarbon chemistry: origing of tropospheric ozone and effects of nonmethane hydrocarbons, J. Geophys. Res., 103(D9), 10757-10767, 1998.

Whalley, L. K., Lewis, A. C., McQuaid, J. B., Purvis, R. M., Lee, J. D., Stemmler, K., Zellweger, C., and Ridgeon, P.: Two highspeed, portable GC systems designed for the measurement of non-methane hydrocarbons and PAN: results from the Jungfraujoch High Altitude Observatory, J. Environ. Monitor., 6, 234241, 2004.

Whalley, L. K., Furneaux, K. L., Goddard, A., Lee, J. D., Mahajan, A., Oetjen, H., Read, K. A., Kaaden, N., Carpenter, L. J., Lewis, A. C., Plane, J. M. C., Saltzman, E. S., Wiedensohler, A., and Heard, D. E.: The chemistry of $\mathrm{OH}$ and $\mathrm{HO}_{2}$ radicals in the boundary layer over the tropical Atlantic Ocean, Atmos. Chem. Phys., 10, 1555-1576, doi:10.5194/acp-10-1555-2010, 2010. 